\title{
Private Nurses and Playboy Bunnies: Explaining Permissible Sex Discrimination
}

\author{
Kimberly A. Yuracko $†$
}

TABLE of Contents

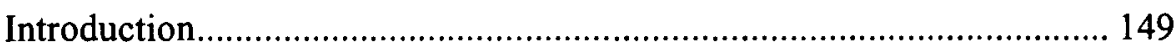

I. The State of the Law ................................................................... 154

II. The Official Story: The Courts' Incoherent Explanation of

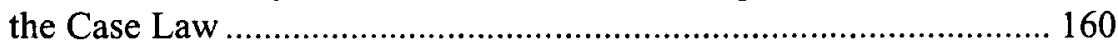

A. The Inherent Theory of Essences.............................................. 161

B. The Shared-Meaning Theory of Essences ................................. 162

C. The Employer-Defined Theory of Essences ................................ 163

D. The Customer-Defined Theory of Essences ................................ 163

E. Explanatory Power of the Essence Theories................................ 166

1. The Privacy Versus Sexual-Titillation Distinction............... 167

2. The Sex Versus Plus-Sex Distinction.................................. 172

III. The Privacy Versus Sexual-Titillation Divide: A More Stable

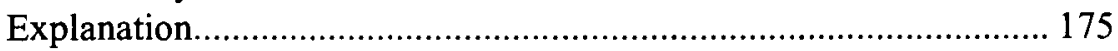

A. Equality of Opportunity …….................................................. 176

1. Individualistic Equality of Opportunity .............................. 176

2. Group-Based Equality of Opportunity …………….............. 178

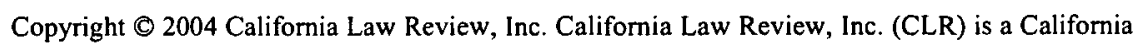
nonprofit corporation. CLR and the authors are solely responsible for the content of their publications.

$\dagger \quad$ Assistant Professor, Northwestern University School of Law. I am grateful for comments and suggestions on earlier drafts from Larry Alexander, Ron Allen, Kathy Baker, Michael Barsa, Cynthia Bowman, Rick Brooks, Ed Cheng, Jenny Diamond Cheng, Paul Davis, Shari Diamond, Barbara Fried, Herma Hill Kay, Mark Kelman, Heidi Kitrosser, Andy Koppelman, Rick Pildes, and Alan Wertheimer. In addition, I received very helpful feedback from the participants at the Northwestern Law School faculty workshop, the Chicago-Kent College of Law workshop, and the Stanford Law School Legal Studies Colloquium. I am also grateful to the Northwestern University School of Law Summer Faculty Research Program for its generous support and to Dean Matthew Spitzer of the University of Southern California Law School for providing me with the perfect environment in which to write the first draft of this paper. I would like to thank my library liaison, Marcia Lehr, and my research assistants, Sarah Kennedy and Lia Monahon, for their invaluable contributions. Finally, I would like to thank Karen Tumlin, Karen Petroski, and the other editors at the California Law Review for an exceptionally thoughtful and caring edit of this Article. 
a. Evidence of Judicial Concern for Group-Based

Equality of Opportunity.

b. Explaining Permissible Sex-Based Discrimination:

Symmetry of Exclusion

c. Explaining Permissible Sex-Based Discrimination:

The Slippery Slope

B. Customer-Focused Perfectionism ............................................. 191

IV. The Sex Versus Plus-Sex Divide: A Better Normative

Approach

A. Explaining Permissible Sex-Based Discrimination:

Judicial Protection of Nonsex Jobs

B. Explaining Permissible Sex-Based Discrimination:

A Worker-Focused Perfectionism. 


\title{
Private Nurses and Playboy Bunnies: Explaining Permissible Sex Discrimination
}

\author{
Kimberly A. Yuracko
}

Discrimination on the basis of sex in employment is illegal-usually. In cases in which employers contend that sex-based hiring is necessary to protect the privacy interests of their customers, however, and in cases in which employers contend that sex-based hiring is necessary to provide a particular type of sexual titillation for their customers, courts sometimes do allow employers to discriminate. Courts say that they allow sex discrimination in employment when it is necessary to preserve the "essence of the business." This Article shows, however, that there is no plausible conception of business "essence" that can explain and make sense of the existing case law. The Article therefore looks beyond the courts' rhetoric to explain and defend why courts distinguish in the ways they do between permissible and impermissible sex discrimination in employment.

\section{INTRODUCTION}

Sex discrimination in employment is illegal-usually. Airlines cannot discriminate on the basis of sex when hiring flight attendants, and restaurants cannot discriminate on the basis of sex when hiring food servers. This is true even if the restaurant or airline explicitly seeks to sell sexual titillation along with food or air travel. Strip clubs, however, can discriminate when hiring strippers, and the Playboy Clubs, before they went out of business, were permitted to discriminate based on sex in hiring Playboy Bunnies. In addition, hospitals can discriminate in hiring nurses to work in labor and delivery rooms, and retirement homes can discriminate in hiring personal care givers for their elderly patients. Even janitorial services can sometimes discriminate in hiring custodians to clean single-sex bathhouses or restrooms.

Why do courts draw the lines they do between permissible and impermissible sex discrimination? Why do courts permit sex discrimination in the hiring of nurses but not in the hiring of waitresses-even if the restaurant is explicitly trying to sell heterosexual male sexual titillation along with its food? Are customer preferences for privacy simply worth more in 
both social and legal terms than customer preferences for sexual titillation? If so, then why do courts permit sex discrimination in the hiring of strippers? Moreover, why do courts distinguish between strip clubs and restaurants in cases where both are seeking to satisfy customer desire for sexual titillation? Why is sex discrimination permissible when sex is being sold alone (or with a good scotch) but not when sex is being sold (or offered for sale) along with air travel or a good hamburger?

While many scholars have recognized the inconsistencies in antidiscrimination jurisprudence, none has either brought theoretical coherence to these decisions or offered a competing framework to explain how courts should have decided these cases. ${ }^{1}$ Robert Post, for example, recognizes that the courts' rhetoric of gender blindness does not explain their actual decisions in Title VII cases. ${ }^{2}$ Post argues that courts use Title VII not to eliminate gender as a social category but to change its meaning in certain contexts and to eliminate sex-based distinctions that are not justified by other widespread social values or norms. ${ }^{3}$ Post does not, however, identify the values and norms actually driving current case law, nor does he offer any normative arguments about the values that should be driving such

1. See, e.g., Robert C. Post et al., Prejudicial Appearances: The logic of american Antidiscrimination Law 1-53 (2001) [hereinafter Prejudicial Appearances] (demonstrating that courts apply antidiscrimination law not to eliminate the social construct of gender but to change its meaning, yet offering no account of the principles that do or should direct the change); Thomas $\mathrm{C}$. Grey, Cover Blindness, in id. at 85 (arguing for consistent formal principles to make sense of the secming inconsistency in current case law addressing bona fide occupational qualifications (BFOQs), but not offering any specifics about what these guiding principles should be); Jillian B. Berman, Defining the "Essence of the Business": An Analysis of Title VII's Privacy BFOQ After Johnson Controls, 67 U. CHI. L. REv. 749, 749-53 (2000) (criticizing courts' permissiveness toward sex discrimination in privacy-based BFOQ cases involving medical care providers and suggesting how courts should deal with these cases, but not addressing or explaining courts' privacy-based BFOQ decisions more generally nor attempting to reconcile the privacy-based cases with sexual titillationbased BFOQ cases); Mayer G. Freed \& Daniel P. Polsby, Privacy, Efficiency, and the Equality of Men and Women: A Revisionist View of Sex Discrimination in Employment, 1981 AM. B. Found. RES. J. $583,587-89,597-601$ (pointing to the many inconsistencies in the "orthodox view" that Title Vll prohibits the drawing of sex-based lines in employment and arguing that the exceptions to the orthodox view turn out "to be simply an instance of discretionary line drawing in which the courts are required to exercise a judgment about the interaction of equality values and other social norms," but not identifying the norms actually motivating the line drawing between privacy and sexual-titillation cases or, within sexual-titillation cases, between sex and plus-sex cases); Rachel L. Cantor, Comment, Consumer Preferences for Sex and Title VII: Employing Market Definition Analysis for Evaluating BFOQ Defenses, 1999 U. CHI. LEGAL F. 493, 508-17 (arguing that courts permit businesses to discriminate on the basis of sex when "sex defines the market in which the business participates," but neither explaining why businesses are not permitted to carve out new market niches defined by the sale of sex along with some other good or service nor addressing why courts permit discrimination in order to protect personal privacy).

2. POST ET AL., supra note 1, at 29-36.

3. Id. Post explains that "as gender norms come to seem more fundamental to a court, it will be correspondingly more reluctant to disturb them. Norms that are fundamental are those that are significant and uncontroversial when seen from the perspective of those implementing the law." Id. at 36. 
decisions. Indeed, Post admits that he does not "argue for any particular set of principles that ought to guide the application of antidiscrimination law."4

Andrew Koppelman offers a more normative theory of antidiscrimination law than Post but still does not adequately explain how courts should distinguish between permissible and impermissible discrimination in the hard cases. Koppelman argues that antidiscrimination law is and should be engaged in a project of cultural transformation aimed at eliminating the unjustified stigma and devaluation attached to groups such as blacks, women, and homosexuals. ${ }^{5}$ Koppelman contends, therefore, that courts were correct to prohibit airlines from hiring only female flight attendants in response to customer preferences because the "customers' preferences, whether for female flight attendants or for male doctors, lawyers, and managers, [were] likely to reflect assumptions of male superiority and female inferiority." Koppelman does not, however, explain how the importance of eliminating stigma should be balanced against other competing social concerns and values. Koppelman does not give guidance as to whether, in addition to prohibiting discrimination in the hiring of flight attendants (and doctors, lawyers, and managers), courts should prohibit sex discrimination in the hiring of strippers, on the grounds that such discrimination also stigmatizes women by reinforcing the social message that women are primarily objects for men's sexual gratification, or whether the potential for stigma attached to such discrimination is more than offset by competing social concerns about respecting personal preferences in certain contexts. In other words, Koppelman, like other scholars, does not offer any reason why courts would or should draw the line where they dopermitting the sex-based hiring of sex workers but not of flight attendants. ${ }^{7}$

This Article seeks to fill this gap in the scholarship by explaining, both positively and normatively, the line drawing that courts have engaged in between permissible and impermissible forms of employment discrimination. In particular, I focus on court decisions regarding when sex constitutes a bona fide occupational qualification (BFOQ) justifying sex discrimination on behalf of a particular employer. The Article seeks to make sense of two types of distinctions courts make in these cases. First, courts distinguish between privacy-based and sexual titillation-based

4. Id. at 41 .

5. See Andrew Koppelman, antidiscrimination Law and Social Equality 8-9 (1996).

6. Id. at 140 .

7. See also K. Anthony Appiah, Stereotypes and the Shaping of ldentity, in PREJUdiciaL APPEARANCES, supra note 1 , at 55, 56 (criticizing the lack of normative push in Post's theory of antidiscrimination law and offering a normative theory similar to Koppelman's). Appiah argues that Wilson v. Southwest Airlines Co., 517 F. Supp. 292 (N.D. Tex. 1981), was rightly decided because the sexualization of flight attendants is "demeaning to women and sustains male supremacy." $I d$. at 70 . But like Koppelman, Appiah offers no guidance for how courts, in applying antidiscrimination doctrine, should distinguish between the sexualization of flight attendants and that of Playboy Bunnies and strippers. 
BFOQ cases, and they are far more permissive of sex discrimination on behalf of privacy concerns than they are of discrimination on behalf of sexual-titillation desires. Second, within the realm of sexual-titillation cases, courts distinguish sharply between businesses selling virtually nothing but sexual titillation-what I call "sex" businesses-and businesses offering or selling sexual titillation along with some other good or service-what I call "plus-sex" businesses. ${ }^{8}$

Despite the inherently different nature of the sexual titillation and privacy issues raised in BFOQ cases, courts offer precisely the same rationale for assessing the permissibility of sex discrimination in both contexts. Officially, in these cases, courts focus on the "essence" of the businesses at issue and permit sex discrimination only if it is necessary to preserve this essence. Yet, how one determines the essence of a business is both facially unclear and radically undertheorized by the courts.

After introducing the current state of the case law in Part I, this Article explores in Part II what courts may mean when they refer to the "essence of a business." I offer four possibilities: (I) essence as inherent meaning, (2) essence as shared social meaning, (3) essence as employer-defined, and (4) essence as customer-defined. I show that none of these possible conceptions can explain the line drawing that courts have engaged in between permissible and impermissible sex-based discrimination. In other words, what the courts say they are doing cannot explain what they are in fact doing.

Despite the emptiness and inadequacy of the courts' own rhetoric, I do not conclude that the distinctions courts make between privacy and sexual titillation and among sexual-titillation cases should be abandoned. To the contrary, I seek to resuscitate these distinctions by providing them with a stronger, more coherent foundation. In Part III, I show that the courts' divergent treatment of privacy and sexual-titillation cases is consistent with and well-justified by both liberal and nonliberal arguments. First, I present several variations of a standard liberal equality-of-opportunity model. I outline an individualistic conception of equality of opportunity and show that this theory offers no leverage with which to understand the courts' decisions. I then outline a fairly standard group-based conception of equality of opportunity and a more subtle slippery slope variation on this argument. I show that a concern with group-based equality of opportunity is clearly present in the courts' BFOQ decisions and helps to explain courts' far greater permissiveness toward sex discrimination in privacy-based, as opposed to sexual titillation-based, BFOQ cases. Privacy cases simply have a

8. One could think of plus-sex businesses as those selling bundled commodities, one of which is sexual titillation. 
"parity of exclusion" that does not exist in sexual-titillation cases, and relatedly, they do not raise the same slippery slope problems. ${ }^{9}$

Second, I present a distinctly perfectionist rationale for the courts' privileging of privacy cases over sexual-titillation cases. Perfectionist theories, in contrast to liberal ones, endorse a substantive conception of the good life. ${ }^{10}$ Proponents of these theories contend that certain ways of life are intrinsically better than others for reasons independent of individual preferences. Moreover, perfectionists contend that government should encourage the values, activities, and ends that are consistent with these better ways of life and discourage those that are not. At least partly driving judicial privileging of discrimination in privacy cases over discrimination in sexual-titillation cases is a customer-focused perfectionism that prioritizes personal preferences and gives greatest weight to those preferences for which respect is deemed most integral to an individual's conception of self and self-worth. Courts simply consider preferences for personal privacy to be more critical to one's sense of dignity and identity than preferences for sexual titillation. Hence, the former are given greater social and legal weight than the latter. This argument, which is explicitly present in the courts' own decisions, provides a more stable and coherent explanation and justification for the courts' decisions than does their essences rhetoric.

In the final Part of the Article, I seek to explain the courts' seemingly strange distinction between sexual-titillation cases involving sex businesses and those involving plus-sex businesses. I argue that while this distinction may be consistent with standard liberal group-based equality-ofopportunity concerns, or with a modified version of the customer-focused perfectionism described above, the strongest normative justification for these decisions is instead a worker-focused perfectionism. This workerfocused perfectionism focuses on the conditions in the work world that are

9. By "parity of exclusion" I mean that there is a rough symmetry between the number of women who will be excluded from jobs to protect men's privacy and the number of men who will be excluded from jobs to protect women's privacy.

10. For a good definition of perfectionism, see Andrew Koppelman, The Fluidity of Neutrality 5 n.4 (Feb. 19, 2002) (unpublished manuscript, on file with author) (explaining that "perfectionism is the view that some ways of life are intrinsically better than others, and that the state may appropriately act to promote these better ways of life"). See also Jeremy Waldron, Autonomy and Perfectionism in Raz's Morality of Freedom, 62 S. CAL. L. REv, 1097, 1102 (1989) (defining perfectionism as "the view that legislators and officials may consider what is good and valuable in life and what is ignoble and depraved when drafting the laws and setting the framework for social and personal relationships"). For a more extensive discussion of perfectionism, see Kimberly A. Yuracko, Perfectionism and CONTEMPORARY FEMINIST VALUES 5 (2003) (defining perfectionism as "the endorsement of a vision of human flourishing and the recognition that certain ways of life are compatible with this vision while others are not"). See also Vinit Haksar, Equality, Liberty, and Perfectionism 3-4 (1979); Thomas Hurka, Perfectionism 3 (1993); Joseph Raz, The Morality of Freedom 417-18 (1986); George Sher, Beyond Neutrality: Perfectionism and Politics 8-10 (1997); Martha C. Nussbaum, Human Capabilities, Female Human Beings, in Women, Culture and Development (Martha C. Nussbaum \& Jonathan Glover eds., 1995). 
necessary to encourage human flourishing in workers." The workerfocused perfectionism privileges intellectual and rational development as crucial for human flourishing and recognizes that women's ubiquitous social sexualization is incompatible with their full intellectual and rational development. Social sexualization distracts women's (and others') attention from their intellectual pursuits and causes women (and others) to focus on their value and success as gaze objects. This division of attention, not surprisingly, results in diminished intellectual functioning and achievement for women. While these harms may not warrant a prohibition of all sex jobs, they provide the strongest justification for courts' unwillingness to permit sexiness and sexual titillation to become requirements for mainstream jobs.

In sum, this Article shows the incoherence and instability of the courts' current BFOQ rhetoric. It does not, however, argue for an abandonment of the distinctions the courts draw between permissible and impermissible forms of sex discrimination. Instead, the Article seeks to provide a more theoretically consistent and normatively persuasive basis for the distinctions.

\section{I}

\section{The State of The Law}

Title VII of the Civil Rights Act of 1964 bars discrimination on the basis of sex in employment. ${ }^{12}$ The bar, however, is not absolute; sex discrimination is permitted where sex is a "bona fide occupational qualification reasonably necessary to the normal operation of that particular business or enterprise." 13

The legislative history of the BFOQ exception is sparse. Those materials that exist suggest that the drafters believed that stereotypes about the skills and attributes possessed by people of a particular sex or national

11. Human flourishing here refers to an objectivc state of individual well-being rather than a subjective state of individual happiness. The nature of the well-being aimed at depends on the substancc of the underlying theory of perfectionism.

12. Title VIl provides: "It shall be an unlawful employment practice for an employer ... to fail or refuse to hire or to discharge any individual, or otherwise to discriminate against any individual with respect to his compensation, terms, conditions, or privileges of employment, bccause of such individual's race, color, religion, sex, or national origin." 42 U.S.C. $\$ 2000 \mathrm{e}-2$ (2000).

13. 42 U.S.C. $\$ 2000 \mathrm{e}-2(\mathrm{e})(1)(2000)$. The full text of the BFOQ exception provides:

Notwithstanding any other provision of this subchapter, (1) it shall not be an unlawful employment practice for an employer to hire and employ employees, for an employment agency to classify, or refer for employment any individual, for a labor organization to classify its membership or to classify or refer for employment any individual, or for an employer, labor organization, or joint labor-management committee controlling apprenticeship or other training or retraining programs to admit or employ any individual in any such program, on the basis of his religion, sex, or national origin in those certain instanccs where religion, sex, or national origin is a bona fide occupational qualification reasonably necessary to the normal operation of that particular business or enterprise.

42 U.S.C. $\$ 2000 \mathrm{e}-2$ (e) (2000). Under the terms of the statute, race never constitutes a BFOQ. 
origin were sufficient to establish a BFOQ. ${ }^{14}$ An Interpretive Memorandum submitted by the Senate floor managers of the bill that became the Civil Rights Act provided examples of discriminatory hiring that would be permissible under the BFOQ exception, including "the preference of a French restaurant for a French cook" and "the preference of a professional baseball team for male players."15

The Equal Employment Opportunity Commission (EEOC), however, has interpreted the statutory exception more narrowly. The EEOC Guidelines interpreting the BFOQ defense provide that stereotypes about the abilities and attributes of the sexes cannot establish a BFOQ. ${ }^{16}$ The Guidelines also explicitly provide that the preferences of coworkers or customers to work with an individual of a particular sex cannot establish a BFOQ. ${ }^{17}$ The EEOC itself has offered limited examples of what would establish a BFOQ. According to the EEOC, sex may be a BFOQ when hiring persons of a particular sex is "necessary for the purpose of authenticity or genuineness." 18 The EEOC provides as an example the hiring of actresses or actors. ${ }^{19}$

Given this lack of statutory clarity and limited administrative guidance, courts have been forced to define the parameters of the BFOQ defense. In practice, sex-based BFOQ defenses are raised primarily in two types of cases. In privacy-based cases, employers argue that they must discriminate on the basis of sex in hiring to protect their customers or other employees from personal or intimate contact with employees of the opposite sex. In sexual titillation-based cases employers argue that they must

14. INTERPRETIVe Memorandum on Title VIl of H.R. 7152, I 10 Cong. Rec. 7212 (1964).

15. Id. at 7213 ; see also Cantor, supra note 1, at 497.

16. The EEOC's Guidelines on Discrimination Because of Sex provide:

(a) The Commission believes that the bona fide occupational qualification exception as to sex should be interpreted narrowly. Labels- "Men's jobs" and "Women's jobs"-tend to deny employment opportunities unnecessarily to one sex or the other.

(1) The Commission will find that the following situations do not warrant the application of the bona fide occupational qualification exception:

(i) The refusal to hire a woman because of her sex based on assumptions of the comparative employment characteristics of women in general. For example, the assumption that the turnover rate among women is higher than among men.

(ii) The refusal to hire an individual based on stereotyped characterizations of the sexes. Such stereotypes include, for examplc, that men are less capable of assembling intricate equipment [and] that women are less capable of aggressive salesmanship. The principle of nondiscrimination requires that individuals be considered on the basis of individual capacities and not on the basis of any characteristics generally attributed to the group.

29 C.F.R. \$1604.2(a) (2002).

17. See 29 C.F.R. $\$ 1604.2(a)(1)($ iii) (2002).

18. 29 C.F.R. $\$ 1604.2(a)(2)(2002)$. The full text of that section provides: "Where it is necessary for the purpose of authenticity or genuineness, the Commission will consider sex to be a bona fide occupational qualification." Id.

19. Id. 
discriminate on the basis of sex in hiring to provide customers with the type of sexual arousal their businesses promise. ${ }^{20}$

Courts have generally been quite permissive toward sex discrimination committed on behalf of customer privacy. The privacy cases can be thought of as falling along a continuum measured by degrees of physical and visual contact. ${ }^{21}$ At the far end of the spectrum are the strongest BFOQ claims, those most likely to succeed. These claims typically involve jobs requiring actual physical contact with or inspection of others' naked bodies. Courts have upheld sex discrimination in such situations based on the intimate nature of the services being provided. ${ }^{22}$ For example, courts have allowed sex discrimination in hiring labor-room nurses, personal caregivers, nurses' aides, and certain other types of hospital staff. ${ }^{23}$

20. It is useful to note that these two types of cases may not in fact be so analytically distinct, since the privacy cases may also be thought of as being about sexuality. While the sexual-titillation cases involve employer attempts to discriminate on the basis of sex in order to sell a particular type of sexuality, the privacy cases may be thought of as involving an effort by employers (and courts) to protect customer chastity or modesty by permitting customers to shield their own sexuality from strangers of the opposite sex. 1 thank Barbara Fried for stressing this point to me.

21. A great many privacy-based BFOQ cases arise in prisons. Although these cases mirror the general privacy continuum described in the text, across the continuum, prisoners' privacy interests receive less deference from courts than do those of nonprisoners. See, e.g., Robino v. Iranon, 145 F.3d 1109,1111 (9th Cir. 1998) (concluding that sex was a BFOQ for hiring guards to a small number of "First Watch" positions in a women's prison, where the positions at issue required the officers on duty to observe inmates in showers and toilet areas); Michenfelder v. Sumner, 860 F.2d 328, 333 (9th Cir. 1988) (noting that prisoners "retain a limited right to bodily privacy"). But see Torres v. Wis. Dep't of Health \& Soc. Servs., 838 F.2d 944, 953 (7th Cir. 1988) (holding that sex was not a BFOQ for guards at a women's prison where the prison had taken steps to protect inmates from being viewed naked by guards of either sex and permitted strip searches only by officers of the same sex); Gunther v. lowa State Men's Reformatory, 612 F.2d 1079, 1087 (8th Cir. 1980) (holding that sex was not a BFOQ for guard positions beyond the entry level when the prison failed to show that it was unablc to modify these positions' duties to protect inmate privacy without denying women career opportunities); Bagley v. Watson, 579 F. Supp. 1099, 1103-04 (D. Or. 1983) (holding that sex was not a BFOQ for prison guards in a male prison because male prisoners did not have a federal or state constitutional right to be free from clothed pat-down frisks and visual observation in states of undress by female guards).

22. See, e.g., EEOC v. Mercy Health Ctr., No. Civ. 80-1374-W, 1982 WL 3108 (W.D. Okla. Feb. 2,1982 ) (holding sex to be a BFOQ for nurses in hospital labor and delivery rooms); Backus v. Baptist Med. Ctr., 510 F. Supp. 1191 (E.D. Ark. 1981), vacated as moot, 671 F.2d 1100 (8th Cir. 1982) (same).

23. See, e.g., Healey v. Southwood Psychiatric Hosp., 78 F.3d 128, 133 (3d Cir. 1996) (permitting sex to be a BFOQ for psychiatric hospital staff treating emotionally disturbed and sexually abused children and adolescents because "[c]hild patients often [had to be] accompanied to the bathroom, and sometimes . . . bathed"); Jones v. Hinds Gen. Hosp., 666 F. Supp. 933, 935 (S.D. Miss. 1987) ("The job duties of male and female nurse assistants and male orderlies often require that such employee view or touch the private parts of their patients."); Fesel v. Masonic Home of Del., 1nc., 447 F. Supp. 1346, 1352 (D. Del. 1978) ("The Home has the responsibility of providing twenty-four hour supervision and care of its elderly guests. Fulfillment of that responsibility necessitates intimate personal care including dressing, bathing, toilet assistance, geriatric pad changes and catheter care. Each of these functions involves a personal touching ...."). But see Olsen v. Marriott Int'l, Inc., 75 F. Supp. 2d 1052 (D. Ariz. 1999) (holding impermissible the consideration of sex in hiring of massage therapists). In Olsen, Marriott's customers overwhelmingly requested female therapists. Although the court noted that massage generally involved a naked customer covered by a sheet or towel and being touched in "intimate areas such as abdominals, inner thighs, and, with [customer's] permission, 
The middle of the BFOQ privacy continuum involves jobs that require an employee to see-but not touch - patients or customers in various states of undress. In these situations too, courts have generally upheld sex discrimination in hiring based on a similar intimacy rationale. ${ }^{24}$

The other end of the privacy continuum is composed of cases in which an employee's duties might cause a client or coemployee embarrassment or discomfort when performed by an individual of the opposite sex, but the duties do not necessarily involve touching or seeing a client's or coemployee's naked body. These cases raise the weakest BFOQ claims, though the claims are still sometimes successful. ${ }^{25}$

Sexual titillation-based BFOQ cases can also be thought of as falling along a continuum. At one end of the sexual-titillation continuum are cases involving jobs in which a particular body is needed and used physically for the sexual gratification of another person. Prostitution and, arguably, lap dancing rest at this end of the sexual-titillation continuum. Though I know of no challenges to the sex-based hiring of prostitutes (where legal) or lap dancers by businesses that employ such workers, it seems likely that courts would permit such sex-based hiring as a BFOQ. ${ }^{26}$

The middle of the sexual-titillation continuum consists of those cases in which the good for sale is not the use of another's body for sexual gratification but the use of another person as a sexual gaze object. As in the cases described above, in these cases sexual titillation is the exclusive good for sale, but the means of producing the arousal differs. Cases involving the sex-based hiring of strippers and Playboy centerfolds fall into this category. Again, courts and commentators have assumed that sex is a BFOQ for these positions. ${ }^{27}$

buttocks," the court held that the privacy interests raised by massage did not justify the Marriott's sexbased hiring of massage therapists. Id. at 1070-74.

24. See Jennings v. N.Y. State Office of Mental Health, 786 F. Supp. 376, $381-82$ (S.D.N.Y. 1992) (permitting sex to be a BFOQ for staffing of treatment assistants at a state-run psychiatric hospital because the positions sometimes necessitated that the treatment assistants view patients naked or partially undressed); Brooks v. ACF Indus., 537 F. Supp. 1122, 1125 (S.D. W. Va. 1982) (holding sex was a BFOQ for cleaning men's bathhouses at a railroad car plant because of the likelihood that male workers would be viewed in various states of undress by the janitor cleaning the bathhouse).

25. Compare Norwood v. Dale Maint. Syst., Inc., 590 F. Supp. 1410,1418 (N.D. 11l. 1984) (holding that sex was a BFOQ for staffing attendants who cleaned single-sex restrooms in a large office building, not because of a concem that office workers might be seen naked by someone of the opposite sex, but because of a concern that office workers would feel "embarrassment" and "increased stress" from being expected to use washrooms in the prcscnce of someone of the opposite sex), with EEOC v. Hi 40 Corp., 953 F. Supp. 301, 303-04 (W.D. Mo. 1996) (holding that sex was not a BFOQ in the hiring of weight-loss counselors, even though the employer's predominantly female clientele was uncomfortable with male counselors taking thcir body-fat measurcments either on bare skin or through clothing).

26. See arthur Larson \& Lex K. Larson, Employment Discrimination $\$ 15.10$, at 4-27 (1992) (contending that the job of a prostitute is an "obvious" example of a BFOQ).

27. See Wilson v. Southwest Airlines Co., 517 F. Supp. 292, 301 (N.D. Tex. 1981) (explaining that "in jobs where sex or vicarious sexual recreation is the primary service provided, e.g. a social 
The other end of the sexual-titillation continuum consists of cases in which employers seek to sell sexual arousal, generally through the provision of gaze objects, along with some other nonsexual good or service. In these plus-sex businesses, the nonsexual good or service being sold can be anything from food to safe air transport. Attempts to discriminate on the basis of sex in hiring for plus-sex businesses are virtually always unsuccessful. $^{28}$

The most famous plus-sex BFOQ case is that of Wilson $v$. Southwest Airlines. ${ }^{29}$ In $197 \mathrm{I}$, Southwest, then a fledgling airline company trying to carve out a market niche for itself, decided, upon the advice of an advertising agency, to conceptualize and market itself as a company selling not only air travel but heterosexual male titillation. ${ }^{30}$ In accordance with Southwest's conceptualization of itself as the "love airline," Southwest hired only women for the high-customer-contact positions of ticket agent and flight attendant. ${ }^{31}$ A class of male job applicants who were denied positions as a result of Southwest's female-only hiring criteria sued the airline. ${ }^{32}$ Despite evidence that Southwest's business had flourished during the "love airline" campaign, the district court rejected Southwest's BFOQ defense, concluding that airlines were in the business of selling safe transport and not sexual titillation. "Like any other airline," the court ruled, "Southwest's primary function is to transport passengers safely and quickly

escort or topless dancer, the job automatically calls for one sex exclusively"); LARSON \& LARSON, supra note 26, at 4-29 (contending that sex is a BFOQ for hiring in businesses where the "distinctive product inherently includes a component of female sexiness"); Larry Alexander, What Makes Wrongful Discrimination Wrong? Biases, Preferences, Stereotypes, and Proxies, 141 U. PA. L. REV. 149, 205 (1992) (noting that hiring only females as strippers is permissible).

28. See, e.g., Wilson, 517 F. Supp. 292 (prohibiting sex discrimination in hiring flight attendants and ticket agents); Guardian Capital Corp. v. N.Y. State Div. of Human Rights, 360 N.Y.S.2d 937 (N.Y. App. Div. 1974) (prohibiting sex discrimination in hiring food servers). An interesting exception to this rule was the hiring of Playboy Bunnies at Playboy Clubs. Bunnies generally served customers food along with sexual eye candy. Despite the plus-sex nature of the business, state adjudicatory bodies held that sex was a BFOQ for hiring Playboy Bunnies. See St. Cross v. Playboy Club, Case No. CSF 22618-70, Appeal No. 773 (N.Y. State Div. of Human Rights Dec. 17, 1971); Weber v. Playboy Club, Case No. CSF 22619-70, Appeal No. 774 (N.Y. State Div. of Human Rights Dec. 17, 1971). Hooters restaurants are perhaps the most obvious current example of a plus-sex business. Although no court has ruled on Hooters' policy of hiring only women as food servers, or "Hooters Girls," 1 assess the strength of the company's BFOQ defense in more detail below. See infra text accompanying note 212 .

29. 517 F. Supp. 292 (N.D. Tex. 1981).

30. See id. at 294. As the court noted, Southwest adopted a specific female personality as its corporate image: “This lady is young and vital ... she is charming and goes through life with great flair and exuberance... you notice first her exciting smile, friendly air, her wit ... yet she is quite efficient and approaches all her tasks with care and attention...'" ld. (ellipses in original). The court continued to note that "[u]nabashed allusions to love and sex pervade all aspects of Southwest's public image. Its T.V. commercials feature attractive attendants in fitted outfits, catering to male passengers while an alluring feminine voice promises in-flight love." Id. at 294 n.4.

31. Id. at 294-95.

32. Id. at 293 .

33. Id. at 295 n.6. 
from one point to another."34 Sexual titillation was "tangential" to Southwest's business and could not justify sex-based hiring. ${ }^{35}$

A similar plus-sex BFOQ defense was unsuccessful in Guardian Capital Corp. v. New York State Division of Human Rights. ${ }^{36}$ Guardian Capital operated a Ramada Inn that contained a dining establishment called the Cabaret. ${ }^{37}$ In July 1972, Guardian Capital sought to change the Cabaret from a standard restaurant to one selling male sexual titillation along with food. To this end, Guardian Capital fired its male waiters and replaced them with female food servers dressed in "alluring costumes." "38 Upon challenge by a laid-off male waiter, the New York Appellate Division rejected the Cabaret's BFOQ defense and held that as a restaurant in the business of selling food, the Cabaret could not engage in discriminatory hiring in order to sell eye candy along with food. ${ }^{39}$

Southwest and Guardian Capital demonstrate that courts simply do not permit employers to explicitly sell sexual titillation along with other goods and services. In rejecting plus-sex BFOQ defenses, courts force these businesses to become traditional nonsex businesses and to abandon their sexual-titillation mission or, alternatively, to adopt a more pure sex focus. $^{40}$

34. Id. at 302 .

35. Id. The court explained:

While possession of female allure and sex appeal have been made qualifications for Southwest's contact personnel by virtue of the "love" campaign, the functions served by employee sexuality in Southwest's operations are not dominant ones. According to Southwest, female sex appeal serves two purposes: (1) attracting and entertaining male passengers and (2) fulfilling customer expectations for female service engendered by Southwest's advertising[,] which features female personnel. As in Diaz, these nonmechanical, sex-linked job functions are only "tangential" to the essence of the occupations and business involved. Southwest is not a business where vicarious sex entertainment is the primary service provided. Accordingly, the ability of the airline to perform its primary business function, the transportation of passengers, would not be jcopardized by hiring males.

Id.

36. 360 N.Y.S.2d 937 (N.Y. App. Div. 1974).

37. Id. at 938 .

38. Id.

39. Id. at 939. In his concurrence, Justice Reynolds noted that this case was difficult to reconcile with the statement in dicta of the New York Human Rights Division that sex was a BFOQ for Playboy Bunnies in Playboy Clubs. Id. Justice Reynolds noted that Guardian Capital was attempting to model itself after the Playboy Club and that "it is difficult ... to understand what the special duties of the 'Bunnies' were that the waitresses in the Cabaret don't have." Id.

40. It is important to note that the plus-sex BFOQ cases that courts have addressed to date have involved employers' attempts to sexualize mainstream businesses by sexualizing jobs that were conventionally nonsexual in nature. There is, however, another strategy that employers wanting to sexualize mainstream businesses could take. Instead of sexualizing traditionally nonsexual jobs, employers could add explicitly and exclusively sexualized jobs to the existing business plan while maintaining conventional nonsexual jobs as such. This is essentially the strategy of the new Hooters Air. Instead of sexualizing flight attendants, as Southwest Airlines did, Hooters Air is structured so that every flight is staffed by nonsexualized coed flight attendants as well as by two explicitly sexualized, and exclusively female, Hooters Girls. See About Hooters Air, at http://www.hootersair.com/about/ press/ (last visited May 4, 2003) (describing the structure of the new airline). Although no court has yet 
The privacy and sexual-titillation cases raise two overarching questions. First, why are courts so much more permissive toward sex discrimination in privacy cases than in sexual-titillation cases? Second, why do courts distinguish among sexual-titillation cases so as to divide the work world into sex and nonsex businesses and to define plus-sex businesses out of existence?

II

\section{The Official Story: The Courts' Incoherent Explanation of THE CASE LAW}

The Supreme Court and lower courts uniformly explain their BFOQ decisions by pointing to the "essence of the business" in each case. ${ }^{41}$ Courts allow sex discrimination only if it is necessary to preserve the essence of the business. In fact, courts seem to invoke "the essence of the business" as something of a mantra, as if saying it often enough will give it meaning. Repetition in this case has not led to clarity. Courts give virtually no guidance on what this phrase means, and, as this Part explains, its meaning is far from facially clear. Indeed, courts often proclaim business essences seemingly out of thin air. ${ }^{42}$

This Part first identifies four possible conceptions of what courts might mean by the essence of a business. These are (1) the inherent theory of essences, (2) the shared-meaning theory of essences, (3) the employer-

ruled on this altemative method of creating a plus-sex business, I discuss below the normative implications of sexualizing mainstream businesses in this way. See infra text accompanying notes 213 14.

41. See Dothard v. Rawlinson, 433 U.S. 321, 333 (1977) (stating that sex discrimination "'is valid only when the essence of the business operation would be undermined" if the business eliminated its discriminatory policy) (quoting Diaz v. Pan Am. World Airways, 442 F.2d 385, 388 (5th Cir. 1971)); see also UAW v. Johnson Controls, lnc., 499 U.S. 187, 206 (1991) (holding that scx discrimination is permissible under the BFOQ exception only if those aspects of a job that allegedly require discrimination fall within the "'essence' of the particular business"); Healey v. Southwood Psychiatric Hosp., 78 F.3d 128, 132 (3d Cir. 1996) (same); Fesel v. Masonic Home of Del., Inc., 447 F. Supp. 1346, 1350 (D. Del. 1978) (same).

42. Note the Fifth Circuit's well-known pronouncement in Diaz that the cssence of the business of airline transportation is to "transport passengers safely from one point to another," while the creation of a "pleasant environment enhanced by the obvious cosmetic effect that female stewardesses provide" is "tangential to the essence of the business." 442 F.2d at 388 . Note also the Supreme Court's pronouncement that "[t]he essence of a correctional counselor's job is to maintain prison security." Dothard, 433 U.S. at 335. Neither the Supreme Court nor the Fifth Circuit explains how it determined security and safe transport, respectively, to be the essence of the prison and airline business, despite seemingly plausible competing essences in each case. Note finally the Supreme Court's decision in PGA Tour, Inc. v. Martin, 532 U.S. 661 (2001), a casc brought under Title Ill of the Americans with Disabilities Act (ADA) rather than under Title VII of the Civil Rights Act. Title III requires public accommodations to accommodate individuals with disabilities so long as the accommodation would not fundamentally alter the nature of the goods or services being provided. In Martin, the Supreme Court ruled that the ADA required the PGA to allow Martin to use a golf cart during tour events because such an accommodation would not fundamentally alter the nature of those events. $I d$. at $683-89$. In reaching this conclusion, the Supreme Court determined that the "essence" of golf was "shot-making," not walking from hole to hole. Id. 
defined theory of essences, and (4) the customer-defined theory of essences. The Part then examines whether any of these conceptions can adequately explain the courts' line drawing between permissible and impermissible sex discrimination. In other words, this Part explores whether courts are really basing their BFOQ rulings on a plausible conception of the essence of the business, or whether this mantra is simply a linguistic and conceptual cover for a substantively different type of analysis.

\section{A. The Inherent Theory of Essences}

One conception of the essence of a business focuses on the timeless, core, and inherent nature of the good or service provided by the business. According to this approach, because certain goods and services have historically consistent and noncontingent essences, the businesses that sell these goods and services have similarly stable and ahistorical essences.

Bernard Williams is most strongly associated with a deeply essentialist argument of this sort. ${ }^{43}$ Williams focuses on the meanings or essences of particular goods, rather than on the essences of particular businesses, but the deep essentialism of his argument is transferable. Williams argues that the inherent, rather than socially contingent, meanings of certain goods dictate the "relevant reasons" according to which such goods must be distributed. ${ }^{44}$ Medical care is his paradigmatic example. Williams argues that because the inherent meaning or internal goal of medical care is curing illness, the proper distribution of medical care should be dictated by medical need; a distribution based on any other criterion, such as wealth or income, is irrational under this theory. ${ }^{45}$

43. Bernard Williams, The Idea of Equality, in Problems of the Self: Philosophical Papers, 1956-1972, at 240 (1973).

44. See id; see also Robert Nozick, ANarchy, State, AND Utopia 233-34 (1974) (noting that "Williams seems to be arguing that if among the different descriptions applying to an activity, there is one that contains an 'internal goal' of the activity, then (it is a necessary truth that) the only proper grounds for the performance of the activity, or its allocation if it is scarce, are connected with the effective achievement of the internal goal"); Michael Walzer, SPHeres of Justice 9 (1983) (explaining that for Williams, the "relevant reasons" by which goods should be distributed "seem[] to connect to essential rather than to social meanings").

45. See Williams, supra note 43 , at $240-41$. Williams explains:

Leaving aside preventive medicine, the proper ground of distribution of medical care is ill health-this is a necessary truth.... Now in very many societies, while ill health may work as a necessary condition of receiving treatment, it does not work as a sufficient condition, since such treatment costs money, and not all who are ill have the money; hence the possession of sufficient money becomes in fact an additional necessary condition of actually receiving treatment. ... When we have the situation in which, for instance, wealth is a further necessary condition of the receipt of medical treatment, we can once more apply the notions of equality and inequality: not now in connection with the inequality between the well and the ill, but in connection with the inequality between the rich ill and the poor ill, since we have straightforwardly the situation of those whose needs are the same not receiving the same treatment, though the needs are the ground of the treatment, this is an irrational state of affairs. 
Despite its theoretical importance, Williams's theory of the inherent meaning of goods has significant shortcomings when applied to the modern business world. ${ }^{46}$ It is not at all clear, for example, what internal goal motivates the distribution of Nike sneakers, Dell computers, or piano lessons. Many goods secm to have no goals independent of what people make of them. As a result, one cannot define the essence of a business sclling such goods merely by looking to the goods themselves.

As Part 1I.E discusses, modern businesses are more mutable and socially constructed than the inherent-essences theory contends. This flaw in the inherent theory of essences suggests, however, a second, more plausible way to conceive of business essences: the essence of a business might be thought of not as something inherent in the business, but as something derived from the shared social meaning currently attached to businesses of that sort.

\section{B. The Shared-Meaning Theory of Essences}

A business might have an essence not in an abstract and metaphysical sense but in a distinctly cultural and linguistic one. Michael Walzer has expressed this less deeply essentialist vision with respect to the "essence" of things. Certain things may be thought to have essences not because of what they are in themselves but because of the social meaning attached to them. ${ }^{47}$ As Walzer explains: "Goods in the world have shared meanings because conception and creation are social processes. For the same reason, goods have different meanings in different societies." ${ }^{\prime 48}$ For example, this theory would suggest that a basketball has no inherent ahistorical meaning that governs what it is for and how it is to be used; instead, the essence of a basketball, that it is for bouncing and playing basketball, derives from the shared social and cultural meanings that we attach to a basketball. The same may hold true for businesses: an airline's essence is air travel rather

46. Williams himself recognizes that many goods do not have inherent essences. Id. More importantly, even Williams's paradigmatic example of medical care may not really have a socially noncontingent internal meaning and goal. Amy Gutmann has pointed out that it is plausible to believe that in Plato's time the purpose of medical care would have been both to cure those who were ill and to retum them to their proper function in the polis. Amy Gutmann, Liberal Equality 102-03 (1980) (arguing that "Williams does not explicitly deal with this seemingly forceful argument that needs are socially and historically relative in ways that defy definitions of the particular and universal needs of human beings"). The proper distribution of medical care would, on this view, be based not only on medical need but also on the likelihood that one would indeed be able to continue to fulfill one's public role if given medical care.

47. WALZER, supra note 44 , at 6-10.

48. Id. at 7. Walzer goes on to explain: "[I]t is the meaning of goods that determines their movement. Distributive criteria and arrangements are intrinsic not to the good-in-itself but to the social good. If we understand what it is, what it means to those for whom it is a good, we understand how, by whom, and for what reasons it ought to be distributed." Id. at 8-9. 
than fine food (or sexual titillation) because this matches our social and cultural understanding of airlines. ${ }^{49}$

\section{The Employer-Defined Theory of Essences}

Alternatively, the essence of a business may be defined not by society but by the business itself. According to this view, the essence of a business is determined not by the nature of the good or service being sold but by the employer's own purposes and goals and by the means the employer has chosen to achieve these goals. ${ }^{50}$ For example, the goal of one local hamburger restaurant might be to combine sexual arousal with culinary satisfaction. In furtherance of its mission, this restaurant sells access to female gaze objects and hamburgers. The goal of another local hamburger restaurant might be primarily to keep children off the streets in the afternoons by giving them a safe place to hang out and do their homework with adult supervision. In furtherance of its mission, this restaurant sells safety, free homework help, and hamburgers. The essences of these two hamburger businesses seem quite different because the owners have very different goals. The owner-defined essence of the first restaurant might justify making sex a job qualification for food servers, while the owner-defined essence of the second might justify making good math, English, and social studies skills job qualifications for food servers.

Robert Nozick suggests a similar theory of business essences with his example of the barber who can shape and structure his barbering business very differently depending on his own purposes, and quite apart from what the business of barbering means to anyone else." Nozick asks: "If someone becomes a barber because he likes talking to a variety of different people, and so on, is it unjust of him to allocate his services to those he most likes to talk to? Or if he works as a barber in order to earn money to pay tuition at school, may he cut the hair of only those who pay or tip him well?"52 The essence of the barbering business in Nozick's example changes depending on the purpose of the business owner.

\section{The Customer-Defined Theory of Essences}

Finally, the essence of a business may be conceived of as being simply whatever the business's customers say it is. Probably the dominant goal of every business is to stay in business and to profit. Satisfying customer preferences is, of course, critical to achieving this goal. Therefore, it may

49. This conception of business essence rests, of course, on an assumption about the relative uniformity with which people view businesses and institutions across society. In fact, such shared and consistent understandings may not exist across different social groups within one society.

50. For an example of this view, see NozICK, supra note 44, at 234.

51. Id.

52. Id. 
make sense to define the essence of a business in terms of the strong customer preferences to which it is responding. For example, if McDonald's customers have strong preferences for French fries but weak preferences for onion rings, one might say that the sale of French fries is part of the essence of McDonald's business in a way that the sale of onion rings is not. Similarly, if customers at a strip club care a lot about seeing naked women but care little about whether the club offers a variety of snack food, one might say that providing gaze objects is part of the essence of a strip club and providing snack food is not.

Two types of customer preferences define each business: preferences for products and preferences for people. Businesses are shaped most obviously by customer preferences for certain goods and services. A business will not stay afloat if there is no customer demand for its good or if its service does not meet customer expectations. Businesses are also shaped, however, by customer preferences for certain types of employees or service providers. Customer preferences to have certain services provided by employees of a particular sex may, for example, be grounded in (1) a belief that individuals of one sex are superior in all or particular activities to individuals of the other sex, (2) socially, or perhaps biologically, conditioned feelings of discomfort at having certain services performed by an individual of a particular sex, (3) a desire to experience or avoid sexual titillation, or (4) a sense of socially or aesthetically appropriate gender roles. At times, these preferences may be largely distinct from the customer's actual experience of the service being performed and may result only in a general level of greater or lesser happiness at knowing the service is (or is not) being performed by a person of the desired sex. For example, a person who does not believe that women should work outside the home may be mildly disturbed by the thought that his mail is being delivered by a female postal carrier, but this knowledge probably has no real effect on his evaluation of the quality of the mail service he receives. At other times, however, these preferences may have more significant and direct effects on how the customer experiences the service being sold. In some cases, a customer's preference for having a service provided by a person of a particular sex materially affects the experienced quality of the service the customer receives.

Alan Wertheimer explains that in situations of this sort, sex becomes a "reaction qualification" for the job at issue. ${ }^{53}$ According to Wertheimer, "[r]eaction qualifications refer to those abilities or characteristics which contribute to job effectiveness by causing or serving as the basis of the appropriate reaction in the recipients. Technical qualifications refer to all other qualifications (of an ordinary sort)." $54 \mathrm{He}$ explains that "reaction

53. Alan Wertheimer, Jobs, Qualifications, and Preferences, 94 ETHICs 99, 100 (1983).

54. Id. 
qualifications are crucial to a wide variety of jobs ... [because] the entire point of many jobs is to elicit the appropriate reaction." 55 These preferences may affect the quality of the service that customers receive for reasons independent of the employee's actual skill. ${ }^{56}$

Consider, for example, the qualifications required of a gynecologist. ${ }^{57}$ One of the primary functions of doctors is to take care of the health of their patients. Doctors are able to care for their patients better when those patients are physically and psychologically comfortable with their doctors. ${ }^{58}$ Patients who are physically comfortable with their doctors will be more likely to visit the doctors when they suspect they have a problem, and patients who are emotionally comfortable with their doctors will be more likely to speak openly about their symptoms and lifestyle. Assume that most women simply feel more comfortable being examined by a female, rather than a male, gynecologist. ${ }^{59}$ If this is the case, then for reasons independent of the technical skill of the doctor, ${ }^{60}$ female gynecologists may provide better medical care to patients. ${ }^{61} \mathrm{~A}$ company that is in the business

55. Id. at 101

56. Of course, customer reactions may affect service quality even when the reactions are wholly independent of conscious preferences. Wertheimer makes this point when he explains that a person's reaction to another may reflect not a preference but just the right "chemistry." Id. at 104. To use Wertheimer's example, young children may have no preference between female and male teachers, but they may actually learn better when taught by women. In such a case, being female may be a reaction qualification for teaching young children, but this qualification is not reflected in actual preference measurements. $I d$. at 107-08. Unconscious reactions of this sort will factor into employers' decisions about how to provide customers with particular types of services and experiences. Part I1.D, however, primarily explores whether business essences are defined by express customer preferences.

57. This is one of Wertheimer's examples of a job in which reaction qualifications may be important. See id. at 101.

58. See Robert R. Ange et al., Stigma in the Line of Face: Self-Disclosure of Patients ' HIV Status to Health Care Providers, 28 J. APPLied Comm. Res. 235, 236 (2000) (citing studies showing that " $[t]$ he relationship with the health care provider plays an important role in patient satisfaction, health, the health care delivery process, and quality of life").

59. Some studies suggest that this is in fact the case. See Pilar N. Ossorio, No Boys Allowed?, J. GENDER-SPECIFIC MED. (Mar. 1999), http://www.mmhc.com/jgsm/archives/99mar.shtml (last visited Sept. 13, 2003); see also Jane Cockburn \& Susan Bewley, Do Patients Prefer Women Doctors?, 103 Brit. J. Obstetrics \& Gynecology 2 (1996); Karen Fennema et al., Sex of Physician: Patients ${ }^{*}$ Preferences and Stereotypes, 30 J. FAM. PRAC. 441 (1990); Esther Haar et al., Factors Related to the Preference for a Female Gynecologist, 13 MED. CARE 782 (1975); Nicole Lurie et al., Preventive Care for Women: Does the Sex of the Physician Matter?, 329 NEw ENG. J. MEd. 478 (1993).

60. See Ossorio, supra note 59 (referring to a study showing that female and male obstetricians are equally likely to be sued for medical malpractice); see also Mary T. Koska, Malpractice Risk the Same for Female and Male Ob-Gyns, Hospitals, Dec. 5, 1992, at 50.

61. Indeed, some studies show that patients are more likely to communicate with female rather than male doctors. See Cockburn \& Bewley, supra note 59, at 2-3; Debra Roter et al., Sex Differences in Patients' and Physicians' Communication During Primary Care Medical Visits, 29 MED. CARE 1083, 1091 (1991) (finding that female and male doctors communicate with their patients differently, with female doctors being more likely to engage in "positive talk," "partnership building," "question asking," and "information giving"). Additionally, women may receive different or better treatment from female obstetricians and gynecologists not simply because of the different ways women respond to female and male doctors but also because of the different ways female and male doctors treat 
of providing good medical care to women and staying profitable may therefore feel that the preferences and reactions of its customers require it to hire only female gynecologists. ${ }^{62}$

Several commentators have argued that businesses can only be understood as responses to customer preferences. Richard Epstein argues that businesses are a multitude of contractual arrangements in which companies seek to satisfy certain customer preferences and demands. ${ }^{63}$ Similarly, Rachel Cantor has argued that a business's essence can be determined only by looking at customer preferences and market demand. ${ }^{64}$

Customer preferences may seem faddish and arbitrary (as in customers' preferences for designer coffees), pernicious (as in male CEOs' preferences for working with male attorneys), or important and legitimate (as in women's preferences for female gynecologists). But whatever their source, a business will not long be in business if it ignores completely customer preferences. ${ }^{65}$ The customer preferences a business seeks to respond to thus offer a fourth possible account of what courts may mean by the essence of a business.

\section{E. Explanatory Power of the Essence Theories}

This Section puts the four essence theories to the test to see if any can fully explain the courts' BFOQ decisions. I focus first on the distinction

patients. See Lurie et al., supra note 59 , at $478-81$ (finding that female physicians are more likely to order preventive tests such as Pap smears and mammograms).

62. Larry Alexander offers another example:

$O$ is a white professional basketball player-the only white on his team-who has becn a fan favorite for many years. He is now past his prime and inferior in skill to some black candidates for the squad. Because management believes that the warmth the fans feel toward $O$ plus their possible antipathy toward a team that has no white players add up to higher gate receipts if $O$ is kept on the team, even at the cost of a somewhat worse record, $O$ 's contract is renewed.

Alexander, supra note 27 , at 174 . O may be considered the best player for the team because of these reaction qualifications rather than because of his technical qualifications.

63. Epstein criticizes the Fifth Circuit's opinion in Diaz v. Pan American World Airways, Inc., 442 F.2d 385 (5th Cir. 1971), by arguing that contracts, and by extension businesses, "do not have "essences." Richard A. Epstein, Forbidden Grounds: The Case Against Employment DisCRiminATION LAws 302 (1992). Instead, Epstein maintains, contracts

have multiple terms and dimensions, and sensible contracting requires parties to make trade-offs at the margin of these many distinct dimensions. The choice that customers make between airlines depends not only on safety (a factor that may differ by only a tiny degree among the major carriers) but also on price, schedule, ground service, food, and of course in-flight service.

Id. Epstein's argument against the notion of essences is itself an argument for essences of a different sort. He is, in effect, arguing that the essence of a business can be defined only in terms of its market responsiveness, with all the complexity this may entail.

64. See Cantor, supra note 1, at 502 ("All of the methods for evaluating BFOQ defenses require a market participation test: are sex-based employment policies necessary for market participation?").

65. Of course, antidiscrimination laws impose some limits on the preferences to which employers may respond. 
courts draw between privacy and sexual-titillation cases and second on the distinctions courts draw between different types of sexual-titillation cases.

\section{The Privacy Versus Sexual-Titillation Distinction}

None of the four possible conceptions of business essence can consistently explain why courts distinguish as they do between privacy and sexual-titillation cases. The inherent and shared-meaning conceptions of business essences are incompatible with the courts' permissiveness toward discrimination in privacy cases, while the employer- and customer-defined conceptions of business essences are incompatible with the courts' restrictiveness toward sex discrimination in sexual-titillation cases.

As stated previously, the idea that most modern businesses have inherent essences is implausible. ${ }^{66}$ Businesses are highly transitory. They are adaptive and responsive to distinct social, economic, and technological trends. They are not static and timeless in the way the inherent-essences model suggests. It is strange, for example, to think of businesses providing janitorial services for large commercial buildings as having an inherent essence. This type of business seems instead to be socially constructed, defined, and understood. The same seems true of modern prisons, mental hospitals, massage parlors, and weight-loss centers. What these businesses are, what they do, and what they mean socially is not only historically and culturally specific, but also specific to the particular prison, hospital, massage parlor, or weight-loss center in question.

Indeed, even if one focuses only on the few businesses for which the inherent theory might seem appropriate, it is difficult to reconcile this inherent conception with the courts' actual BFOQ decisions. If, for example, the inherent essence of hospitals and medical centers is the provision of appropriate medical care, this essence neither demands nor justifies the sex-based hiring of nurses. Medical care entails a range of different and varied tasks and responsibilities, all of which can technically be performed by both female and male workers. The inherent essence of the medical care business can justify sex-based hiring of nurses only if one both (1) conceives of the inherent essence as the provision of not only appropriate medical care but medical care of the highest quality, and (2) believes that because of reaction qualifications, patients actually receive better care from same-sex nurses. However, any assertion about the superiority of same-sex nursing care is controversial and is, unsurprisingly, not relied upon by courts to permit such discrimination. ${ }^{67}$

66. See supra note 46 and accompanying text.

67. Instead, courts ground decisions permitting the sex-based hiring of nurses on findings that individuals prefer to have nurses of the same sex. These courts do not base their decisions on any findings or conclusions about the superiority of care that individuals receive from same-sex nurses. See Jones v. Hinds Gen. Hosp., 666 F. Supp. 933, 936 (S.D. Miss. 1987) (focusing on patient preferences for same-sex caregivers but not extending the analysis to whether patients subjectively or objectively 
Like the theory of inherent essences, the shared-meanings conception of business essence only has power to explain the courts' nursing decisions if one (1) defines the shared meaning of hospitals and medical centers as providing not merely adequate and appropriate care but care of the highest quality, and (2) adopts an explicit theory about why reaction qualifications require same-sex care. ${ }^{68}$ Courts' failure to adopt an explicit theory of reaction qualifications in this context suggests that the shared-meaning theory also does not drive their decisions to permit sex-based discrimination in nursing cascs.

The shared-meaning theory is even less successful at explaining courts' decisions in other privacy-based cases. For example, the sharedmeaning conception fails to justify courts' permissiveness toward sex discrimination in the hiring of janitors and custodians to clean single-sex bathrooms. It is probably uncontroversial that the essence of a custodial company, according to the shared-meanings view, is to provide cleaning services. As with the provision of medical care, individuals of either sex are equally able to perform the technical aspects of cleaning, and therefore sex discrimination is not required by this version of business essence. ${ }^{69}$ Unlike in the nursing cases, however, no plausible reaction qualification argument could potentially salvagc the shared-meaning approach as a justification for sex-based hiring in this context. That is, even if the essence of a custodial business were to provide the best possible cleaning service, rather than just adequate cleaning, it would be implausible to contend that clients and customers actually experience the cleanliness of a bathroom differently depending on the sex of the cleaner. People may prefer having same-sex custodians, especially if the custodians are in the restroom when the customers use it, but this is for reasons independent of the real or experienced level of cleanliness that custodians of each sex provide.

In contrast to the inherent and shared-meaning conceptions of business essences, the employer-defined theory of business essences is consistent with courts' general permissiveness toward sex discrimination in privacy cases, since sex discrimination is required by the essence of a

received better care under such circumstances); Backus v. Baptist Med. Ctr., 510 F. Supp. 1191, 1196 (E.D. Ark. 1981) (same). The fact that courts do not extrapolate from their findings about patient preferences to a conclusion about reaction qualifications and their effect on patient care suggests that the courts do not need to do so. It suggests that in fact courts are simply responding to customer preferences rather than relying on the more complex combination of a theory of reaction qualifications with a theory about the inherent essence of hospitals as being to provide the best possible medical care.

68. If this were the conception of business essence motivating courts' decisions in the nursing cases, courts would necessarily inquire not only into patients' simple preferences for same-sex care but also into whether such preferences affect patients' experienced quality of care. Courts do not undertake this second inquiry.

69. Indeed, as in the nursing cases, neither the courts nor the employers in the custodian cases contend that individuals of the excluded sex are incapable of performing the job or that the exclusion is required by the goal of clean bathrooms. See, e.g., Norwood v. Dale Maint. Sys., 590 F. Supp. 1410 (N.D. 111. 1984); Brooks v. ACF lndus., 537 F. Supp. 1122 (S.D. W. Va. 1982). 
business, under this view, whenever an employer says it is. ${ }^{70}$ Indeed, in some privacy cases courts do suggest that they are applying the employerdefined conception of business essences. For example, in Torres $v$. Wisconsin Department of Health and Social Services, male correctional officers who were reassigned out of a women's maximum-security prison sued, alleging sex discrimination. ${ }^{71}$ The superintendent of the prison defended by arguing that sex was a BFOQ for correctional officers in the prison's living units because having exclusively female correctional officers in the prison living units was critical to the rehabilitation of the female inmates. In assessing this BFOQ defense, the court stressed that the essence of the business had to be determined not by looking at businesses of that sort generally but by looking at that particular business. ${ }^{72}$ The court noted that "[o]ftentimes, this task requires that a court recognize factors that make a particular operation of an employer unique or at least substantially different from other operations in the same general business or profession."73

Despite occasional gestures by courts toward this conception of business essences, courts do not consistently interpret the essences of businesses in this way. If the essence of a business were simply what an employer said it was, then certainly Southwest would have been permitted to discriminate on the basis of sex in hiring flight attendants/gaze objects, ${ }^{74}$ and the Cabaret would have been justified in discriminating on the basis of sex in hiring food servers/gaze objects. ${ }^{75}$ The sale of heterosexual male sexual titillation through the display of female gaze objects was essential to each business as conceived and defined by the employers. Yet, courts refused to defer to employers' plus-sex definition of their businesses. ${ }^{76}$

70. The theory does not, however, explain courts' refusal to permit sex discrimination in privacy cases involving massage therapists and weight-loss counselors.

71. 859 F.2d 1523 (7th Cir. 1988) (en banc).

72. Id. at 1528 .

73. Id. In this case, the court concluded that inmate rehabilitation was clearly related to the essence of the prison's business, but the court remanded the case to the district court to consider whether the prison had presented sufficient evidence showing that sex-based hiring was indeed reasonably necessary to further the goal of rehabilitation. Id. at 1530-32. See also Chambers v. Omaha Girls Club, Inc., 834 F.2d 697, 703-04 (8th Cir. 1987). In Chambers, the court upheld a private girls club's firing of an arts and crafts instructor for becoming pregnant while unmarried. The club argued that it had been justified in firing the instructor because the essence of its business was to help young girls maximize their life opportunities, and this essence required that all instructors act as role models for the girls. The court deferred completely to the club's assertions about what its business essence entailed and the type of role modeling required by it.

74. See supra notes 29-35 and accompanying text.

75. See supra notes $36-39$ and accompanying text.

76. Richard Epstein refers to the kind of court-based business restructuring that courts engaged in with respect to Southwest and the Cabaret as the "coercive nature of the antidiscrimination law." See EPSTEIN, supra note 63, at 308. Epstein bemoans the fact that "[i]t is no longer sufficient to treat the job as though it were a given and then to ask what its qualifications are. Instead, the employer is always 
Finally, the customer-defined conception of business essences fails to reconcile the courts' privacy and sexual-titillation cases. Customer preferences alone cannot justify courts' permitting sex discrimination in businesses raising privacy concerns but prohibiting sex discrimination in plussex businesses even when the strength of the customer preferences for employees of a particular sex is comparable.

Courts have allowed sex discrimination in privacy-related cases based on a range of different types of customer-preference evidence. Judicial approval of sex discrimination in hiring nurses has turned on evidence that some, but not all, of the facility's clients preferred to receive treatment from individuals of their own sex. For example, in Fesel v. Masonic Home of Delaware, Inc., the court held that sex was a BFOQ for nurses' aides caring for elderly women in a residential retirement facility based on evidence that nine female guests (out of a total of twenty-two female guests) who were approached by the Director of Nursing Services said that they objected to male nurses and male nurses' aides caring for them. ${ }^{77}$ Similarly, in EEOC v. Mercy Health Center, the court found that sex was a BFOQ for nurses in the hospital's delivery rooms based on a written survey indicating that "sixty to seventy percent of the mothers and a larger percentage of the fathers objected to the use of male nurses in the labor and delivery area."

In Wilson v. Southwest Airlines Co., Southwest presented market data showing —at least as convincingly - that its customers had a strong preference for sexual titillation along with their air travel. ${ }^{79}$ In the years following its initiation of the "love campaign," Southwest made great strides in carving out a significant niche in the air travel industry for itself. According to the district court, "[f]rom 1979 to 1980 , the company's earnings rose from $\$ 17$ million to $\$ 28$ million when most other airlines suffered heavy

told by degrees that some internal adjustment to the business must be undertaken in order to make jobs equally available to men and women." $I d$.

77. 447 F. Supp. 1346, 1352 (D. Del. 1978).

78. No. Civ. 80-1374-W, 1982 WL 3108 , at *3 (W.D. Okla. Feb. 2, 1982). Courts have upheld sex-based hiring in other nursing cases based on even more speculative evidence of customer preferences. In Jones v. Hinds General Hospital, 666 F. Supp. 933 (S.D. Miss. 1987), and Backus v. Baptist Medical Center, 510 F. Supp. 1191 (E.D. Ark. 1981), the courts held that sex was a BFOQ in the hiring of hospital orderlies and obstetrics and gynecology nurses, respectively, based on testimony from doctors and nurses at the hospitals that they believed that significant numbers of their patients would object to being cared for by orderlies or nurses of the opposite sex. Jones, 666 F. Supp. at 936 (noting, in support of its conclusion that sex was a BFOQ for hospital orderlies performing caretaking duties for male patients, that "[b]ased on the testimony of defendant's witnesses, including ... [the] Assistant Hospital Administrator, two head nurses,... and ... a urologist who practices at the Hospital, it was evident that a significant number of male patients object to being exposed to female nurse assistants"); Backus, 510 F. Supp. at I196 (holding that sex was a BFOQ for labor and delivery nurses in the OB-GYN department of the hospital, and noting that the hospital had presented evidence from doctors, nurses, and supervisors that they believed a majority of their patients would object to being treated by male nurses).

79. 517 F. Supp. 292, 295 (N.D. Tex. 1981). 
losses." 80 Moreover, the court attributed Southwest's success largely to its marketing strategy of selling sexual titillation along with air travel:

Southwest has enjoyed enormous success in recent years. This is in no small part due to its marketing image. Though Southwest now enjoys a distinct advantage by operating its commuter flights out of "convenient" Love and Hobby Fields, the airline achieved a commanding position in the regional commuter market while flying "wing tip to wing tip" with national carriers who utilized the same airport, fares, schedules, and aircraft. The evidence was undisputed that Southwest's unique, feminized image played and continues to play an important role in the airline's success. ${ }^{81}$

Despite these market indications that Southwest's customers chose the airline over other carriers because of the added dimension of sexual arousal on Southwest's flights, the court still held that sex was not a BFOQ for flight attendants or ticket-counter workers at Southwest. ${ }^{82}$

If courts were simply basing their determinations on the strength of customer preferences for particular goods and services, there would be no reason to distinguish between privacy and sexual-titillation cases when customer preferences for each are equivalently strong. ${ }^{83}$ Yet, courts consistently permit sex discrimination to protect personal privacy but prohibit it when the goal is sexual titillation, even when customers appear to want sexual titillation as much as they want privacy.

In sum, none of the four possible conceptions of business essences can explain why courts distinguish between privacy and sexual-titillation BFOQ cases in the ways they do. Similarly, as I will discuss below, none

80. Id. at 295 n.6.

81. Id. at 295 .

82. Ten years earlier, Pan Am had presented similarly strong evidence of customer preferences for female flight attendants to support its defense that sex was a BFOQ for these positions. Although in that case the district court found that passengers "overwhelmingly prefer[red] being served by female stewardesses," the court of appeals held that sex was not a BFOQ for hiring flight attendants. Diaz v. Pan Am. World Airways, Inc., 442 F.2d 385, 387 (5th Cir. 1971). The court of appeals explained: "While we recognize that the public's expectation of finding one sex in a particular role may cause some initial difficulty, it would be totally anomalous if we were to allow the preferences and prejudices of the customers to determine whether the sex discrimination was valid." $I d$. at 389.

83. Indeed, the customer-defined theory of essenccs is also unablc to explain consistently the courts' decisions in privacy cases. For example, while in EEOC v. Mercy Health Center the district court permitted sex-based hiring of nurses based on evidence that $60 \%$ to $70 \%$ of the mothers in the

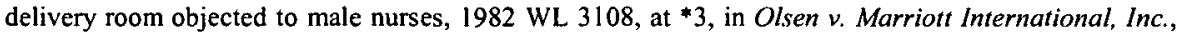
the district court held that sex was not a BFOQ for hiring massage therapists despite Marriott's evidence that $72 \%$ of its clients (in this case both malc and female) preferred female massage therapists to male therapists, Olsen, 75 F. Supp. 2d 1052, 1063, 1074 (D. Ariz. 1999). In Jones v. Hinds General Hospital and Backus $v$. Baptist Medical Center, courts permitted the sex-based hiring of nurses and orderlies based on the employers' beliefs that patients would object to personal care from persons of the opposite sex. Jones, 666 F. Supp. at 936; Backus, 510 F. Supp. at 1196 . However, in EEOC v. Hi 40 Corp., the court refused to find that sex was a BFOQ for weight-loss counselors at Physicians Weight Loss Centers despite being presented with evidence showing that the centers' overwhelmingly female clientele would not in fact accept counseling from men. 953 F. Supp. 301, 304 (W.D. Mo. 1996). 
of the four conceptions of business essences can explain why courts distinguish among sexual-titillation cases in the ways they do.

\section{The Sex Versus Plus-Sex Distinction}

Essence theories fail to explain the line courts draw between sex and plus-sex businesses. None of the four essence theories gives a satisfactory account of the reasons courts rigidly distinguish between sex businessesthose that sell sexual titillation as virtually their only good-and plus-sex businesses-those that sell sexual titillation along with other nonsexual goods and services. Courts permit sex discrimination in the former while effectively defining the latter out of existence.

The inherent essence theory does not help to make sense of courts' distinctive treatment of sex and plus-sex businesses. The sex industry may be one of the few arenas in which the conception of inherent business essence has some traction. This view may justify courts' allowance of sex discrimination in the hiring of sex workers. Consider prostitution aimed at heterosexual men. Arguably, the inherent essence of heterosexual prostitution is vaginal intercourse. If this is so, then the essence of heterosexual prostitution requires sex discrimination in the hiring of prostitutes.

Prostitution is, of course, broader than heterosexual intercourse, and sex work is broader than prostitution. Sex work also includes lap dancing, stripping, and acting as a sexualized gaze object. Unlike heterosexual intercourse, these activities can technically be performed by individuals of either sex. Yet, all these other forms of sex work might also be thought to have inherent essences that require customer sexual stimulation. Therefore, sex discrimination might be required by the inherent essences of these broader forms of sex work-not because individuals of the disfavored sex are unable to perform the acts desired, but because of the depth and relative stability of customers' sexual preferences. That is, the sex of the person trying to arouse them really does matter for people's sexual stimulation.

The inherent view of essences, therefore, has some potential for explaining courts' willingness to permit sex discrimination by businesses in the sex industry. It does not, however, explain courts' complete unwillingness to permit sex discrimination by plus-sex businesses. If sex-based hiring is necessary to preserve the inherent essence of a business that is selling sexual stimulation alone, it should be equally necessary to preserve the essence of a business that is selling sexual stimulation along with some other good or service. Yet, while courts permit sex discrimination in the first scenario, they prohibit it in the second.

The shared-meaning conception of business essences is likewise unable to explain the rigid distinction courts maintain between sex and plussex businesses, permitting discrimination in the former but not in the latter. Under the shared-meaning theory, the essence of a business is determined 
by the linguistic and social meanings attached to that particular business. Restaurants are for serving food. Airlines are for safe air travel. Strip clubs are for sexual titillation. As a result, the theory goes, sex discrimination is not permitted in the hiring of waitstaff or flight attendants because the service of food and provision of safe air travel do not require employees of one sex or the other. Sex discrimination is, however, permitted in strip clubs, because sexual titillation of a particular target audience depends on the sex of the strippers.

But if business essences are defined by social and linguistic conventions, this does not explain why courts prevent employers from stepping outside conventional boxes and establishing new kinds of businesses without preexisting social meanings. If the essence of a restaurant is to sell food, cannot an employer simply say that she is not in the restaurant business but in the "sextaurant" business and that she is seeking to discriminate on the basis of sex not in hiring waitresses, but in hiring "sextresses"? The essence of a sextaurant, the owner would argue, is to sell food and heterosexual male sexual titillation. Unlike regular waitresses, sextresses are in fact required to act as sexual gaze objects in addition to food servers. Similarly, an employer could argue that he is not in the airline business but rather in the "airgaze" business, which provides air travel plus sexual arousal through the presentation of sexy female gaze objects. This employer seeks to discriminate on the basis of sex not in hiring flight attendants but in hiring what he might describe as airgaze girls. The essence of the airgaze business, as opposed to that of the airline business, is safe travel plus heterosexual male sexual titillation. As in the hiring of sextresses, sex discrimination is indeed required in the hiring of airgaze girls.

Of course, these examples are not fanciful. They were the arguments made by Guardian Capital ${ }^{85}$ and Southwest Airlines. ${ }^{86}$ Both companies developed new business strategies intended to increase profits by relying explicitly on the sale of sexy female gaze objects in addition to their traditional goods: food and air travel. ${ }^{87}$ In both cases, the courts refused to

84. This is basically the "doctoring-schmoctoring" argument Nozick makes against Williams's argument that medical care must be distributed according to need. As Nozick notes, even if the essence of medical care dictates that doctoring services be distributed according to medical need, what is to prevent someone from saying that she is in the business not of doctoring but of schmoctoring, "an activity just like doctoring except that its goal is to earn money for the practitioner"? See Nozıck, supra note 44, at 234 .

85. See Guardian Capital Corp. v. N.Y. State Div. of Human Rights, 360 N.Y.S.2d 937, 938 (N.Y. App. Div. 1974).

86. See Wilson v. Southwest Airlines Co., 517 F. Supp. 292, 293-94 (N.D. Tex. 1981).

87. See Guardian Capital, 360 N.Y.S.2d at 937; Southwest, S17 F. Supp. at 292. This was also the strategy of Hooters Restaurants. In response to a sex discrimination lawsuit brought by men denied positions as food servers at the establishments, Hooters argued that sex was a BFOQ for its food servers because the restaurant was explicitly selling not only food but heterosexual male arousal through its sexy, young, scantily clad, and exclusively female wait staff. The case settled before a court could rule 
allow the employers to bundle the sale of sex and nonsex goods and services. ${ }^{88}$

In the Southwest case, the district court had help in determining the essence of a traditional airline from the Fifth Circuit, which had spoken on the matter ten years earlier in Diaz v. Pan American World Airways. ${ }^{89}$ In rejecting Pan Am's BFOQ defense for its policy of hiring only female flight attendants, the court of appeals asserted that " $[\mathrm{t}]$ he primary function of an airline is to transport passengers safely from one point to another."90 The court continued:

While a pleasant environment, enhanced by the obvious cosmetic effect that female stewardesses provide as well as, according to the finding of the trial court, their apparent ability to perform the non-mechanical functions of the job in a more effective manner than most men, may all be important, they are tangential to the essence of the business involved. ${ }^{91}$

Despite Southwest's explicit and determined attempts to create a new kind of air-travel business_-one explicitly selling transport plus sexual titillation-Southwest was not allowed out of the conventional airline box. The court treated Southwest like, and forced it to act like, a traditional airline. ${ }^{92}$ Thus, the shared-meaning thcory may explain why traditional businesses are defined in particular ways, but the theory cannot explain why employers are not free to define businesses as being outside of the traditionally recognized forms. ${ }^{93}$

on Hooters' BFOQ argument. See Kenneth L. Schneyer, Hooting: Public and Popular Discourse About Sex Discrimination, 31 U. MiCH. J.L. ReForm 551, 567 (1998).

88. Guardian Capital, 360 N.Y.S.2d at 937; Southwest, 517 F. Supp. at 293.

89. 442 F.2d 385 (5th Cir. 1971).

90. Id. at 388. The Fifth Circuit also noted that many other airlines used both men and women as flight attendants. Even Pan Am, at the time of the lawsuit, had " 283 male stewards employed on some of its foreign flights." Id.

91. Id.

92. See supra note 35 .

93. Borrowing from Wittgenstein, one might argue that language must be shared to have meaning and that shared meaning limits the new forms businesses can take. See Ludwig WITTGENSTEIN, Philosophical Investigations para. 355 (G.E.M. Anscombe trans., 2d ed. 1967). The Cabaret cannot just redefine itself as a sextaurant, the argument goes, because sextaurants do not exist within our shared social meanings. From both a philosophical and practical perspective, however, businesses are not so constrained. From a philosophical perspective, adopting Wittgenstein's argument that language must be public and shared to have meaning does not explain why businesses cannot use existing language to define new terms and businesses. From a practical perspective, this is what businesses do all the time - think of the popular understanding of such new business entities as cell-phone companies, website design firms, and internet cafes.

1t is simply not the case that businesses are prevented from carving out new business niches and creating new names for these niches because of the limits of our existing shared language. The restrictiveness on business innovation imposed by courts in the plus-sex arena is not an interesting example of a profound philosophical phenomenon but rather an example of an interesting and anomalous practical phenomenon grounded in the courts' unique legal treatment of plus-sex businesses. 
The conception of business essences as employer-defined is unable to explain the courts' sexual-titillation decisions for basically the same reason. If the essence of a business were only what an employer said it was, then Southwest would have been permitted to discriminate in the hiring of its airgaze girls for its airgaze business, and the Cabaret would have been justified in discriminating in hiring sextresses for its sextaurant. The sale of heterosexual male sexual titillation through the display of female gaze objects was essential to each business as conceived and defined by both employers.

The theory of customer-defined business essences similarly fails to account for courts' divergent treatment of sex and plus-sex businesses. If the essence of a business were defined by strong customer preferences, then strong preferences for sexual titillation would justify sex discrimination regardless of whether the preferences were for sex alone or for something else plus sex. This theory therefore cannot explain why preferences for sexual titillation are suddenly not respected when expressed along with preferences for other goods. ${ }^{94}$

In sum, the courts' official story about their BFOQ rulings cannot explain their actual decisions. The courts' consistent reference to "the essence of the business" in explaining their BFOQ decisions is an unsatisfactory basis for those decisions since no coherent theory of business essences can explain the distinctions made in the case law. No single account of the "essence" of a business can reconcile the courts" privacy-based BFOQ decisions with their sexual-titillation decisions, or their sexual-titillation decisions relating to sex businesses with their decisions relating to plus-sex businesses. In the following Parts of this Article, therefore, I move away from these official explanations and present an alternative story that better explains current BFOQ case law.

\section{III}

The Privacy Versus Sexual-Titillation Divide:

\section{A More Stable Explanation}

As Part II shows, no single essence theory fully explains-either normatively or descriptively - the lines courts draw in sex discrimination cases. In this Part, 1 present two alternative theories that better account for the courts' distinctive treatment of privacy-based and sexual titillationbased cases.

Courts' far greater leniency toward sex discrimination in privacy cases than in sexual-titillation cases can be explained by concerns about equal-opportunity norms and by a distinctly perfectionist theory of

94. Indeed, as noted previously, customer preferences for sexual titillation in plus-sex cases are scemingly as strong as the preferences for privacy expressed in privacy-based BFOQ cases and respected by courts. See supra text accompanying notes 77-82. 
customer preferences. These concerns arc explicitly present in the courts' decisions and provide a stronger justification for these decisions than does judicial rhetoric about essences.

\section{A. Equality of Opportunity}

Courts' privacy-based BFOQ decisions demonstrate a concern about the effects sex discrimination will have on the job opportunities of the excluded sex. In this Section, I explore how well equal opportunity-based concerns explain and justify the divergent treatment courts give to sex discrimination in privacy- and sexual titillation-based BFOQ cases. I show that while a standard individualistic theory of equal opportunity-one focused on fairness to the individual - provides no leverage in making sense of the courts' privacy and sexual-titillation decisions, a group-focused theory of equal opportunity - one focused on fairness to the group rather than to the individual-provides significant leveragc in explaining courts' decisions.

\section{Individualistic Equality of Opportunity}

An individualistic conception of equality of opportunity requires that individuals who are alike in relevant respects be treated alike and given the same chances for success. Reva Siegel notes that "[i]t is understood to be the essence of meritocratic rationality, or so-called 'equality of opportunity,' to classify persons with respect to 'socially relevant characteristics' which are taken as goods, or proxies for goods, in themselves." 95 This individualistic conception of equality of opportunity is the most standard conception of equal opportunity relied on by courts in antidiscrimination cases ${ }^{96}$ and provides the paradigmatic model of antidiscrimination law. ${ }^{97}$ Unfortunately, the individualistic conception of equality

95. Reva B. Siegel, Discrimination in the Eyes of the Law: How "Color Blindness" Discourse Disrupts and Rationalizes Social Stratification, 88 CALIF. L. REV. 77, 92-93 (2000); see also Gabriël A. Moens, Equal Opportunities Not Equal Results: "Equal Opportunity" in European Law After Kalancke, 23 J. LEGIS. 43, 44 (1997) ("Equality of opportunity allows individuals to compete for employment solely on the basis of characteristics relevant to satisfactory performance, and not on the basis of generally extraneous factors such as sex or race.").

96. See Connecticut v. Teal, 457 U.S. 440, 451 (1982) (making clear that an employer must evaluate each employee individually with respect to relevant job requirements and cannot avoid a finding of discrimination by pointing to its overall hiring record for individuals of the employee's social group); Fumco Constr. Corp. v. Waters, 438 U.S. 567, 579 (1978) ("It is clear beyond cavil that the obligation imposed by Title VIl is to provide an equal opportunity for each applicant regardless of race, without regard to whether members of the applicant's race are already proportionately represented in the work force.").

97. See Siegel, supra note 95, at 89-90 ("When antidiscrimination law asks whether discrimination has occurred, it typically inquires whether the challenged action differentiates among persons 'rationally,' examining how persons are grouped or classified with respect to 'traits' that might be 'relevant' to the 'purpose' of the regulatory action or law."); see also DeboraH L. RHODE, JuSTICE and Gender: Sex Discrimination and THE LAW 81 (1989) ("American [discrimination] analysis 
of opportunity has no power to explain the BFOQ case law. Rather than clarifying these decisions, the individualistic conception simply brings us full circle to the question of the previous Part-namely, how one determines the essence of a business.

Consider first a world in which employers are free to determine the requirements for jobs however they want. In this world, the owner of a private nursing home for elderly women defines the job of nurse as requiring basic medical skills and femaleness in order to respect customers' preferences not to be touched or viewed by men while unclothed. Given this definition of the relevant features of the job, the employer's sex-based hiring of nurses does not raise any individualistic equal opportunity problems. Men who are denied nursing jobs at the home are not being denied equal opportunity. They are being denied jobs simply because they are different from, and less qualified than, women in the respects that are relevant to the job.

Similarly, consider the case of a restaurant owner who defines food server positions as requiring that individuals be able to serve food adequately while also acting as arousing gaze objects for heterosexual men. Again, if the employer's definition of this service job is accepted, then male applicants are not being denied equal opportunity when they are denied food server jobs. They are being denied the jobs because women and men are not equally qualified to act as sexually arousing gaze objects for heterosexual men. Therefore, to the extent employers are permitted to define their own businesses and jobs, sex-based hiring in either privacy or sexual-titillation cases does not violate the requirements of individualistic equality of opportunity.

Of course, as discussed in the last Part, courts do not simply permit employers to define their businesses in any way that they want. Instead, courts intercede and at times override employers' own stated business requirements. However, when courts rather than employers define the relevant characteristics of a particular job, it becomes impossible to explain the courts' decisions by reference to individual equality of opportunity. A model of equal opportunity that demands only that people with the same relevant characteristics be treated the same cannot itself provide direction for courts in determining what is and is not a relevant characteristic and hence when sex discrimination is and is not permissible.

The courts' BFOQ decisions thus cannot be motivated and informed by this individualistic conception of equality of opportunity. To the extent that jobs are defined by employers, the types of discrimination the courts have prohibited do not raise equal-opportunity problems. To the extent that

has developed largely within an Aristotelian tradition that defines equality as similar treatment for those similarly situated. Under this approach, discrimination presents no legal difficulties if the groups differ in ways relevant to a valid regulatory objective."). 
jobs are defined by courts, their BFOQ decisions must necessarily be based on something other than the substantively empty requirement that individuals who are alike with respect to their relevant qualifications be treated alike.

\section{Group-Based Equality of Opportunity}

A group-based theory of equality of opportunity is far more useful in explaining the courts' privacy versus sexual-titillation distinction. ${ }^{98} \mathrm{~A}$ group-based theory contends that certain social groupings, for example women and men, should face (either approximately or exactly) the same numbers and types of employment opportunities. ${ }^{99}$ This view does not contend that different groups should be equally successful in their quests for jobs, but simply that members of those groups should have the same opportunities to compete for the vast majority of public-sphere jobs on the same non-sex based terms. Underlying this conception of equality of opportunity is, necessarily and critically, the substantive belief that sex is irrelevant to the vast majority of jobs. It is this underlying substantive belief about the nature of relevant job criteria in the work world that links this second theory of equal opportunity with the first and takes it a step beyond. This second conception of equal opportunity, because of its underlying theory

98. Both Alan Wertheimer and Larry Alexander argue that such group-based equality-ofopportunity concerns should inform courts' determinations of the essential features of particular jobs and their determinations of when sex discrimination in furtherance of these essences is permissible. Alexander notes:

My tentative conclusion is that the morality of one's treatment of reaction qualifications is not primarily a function of the intrinsic morality or immorality of the reactions. Rather, the morality of the chosen treatment is primarily a function of both considering the gravity and the distribution of the social effects of acknowledging reaction qualifications and the gravity and distribution of the social effects of not acknowledging them.

Alexander, supra note 27, at 176. See also Wertheimer, supra note 53, at 110-11 ("[1]f counting reaction qualifications seriously compromises one's range of employment opportunities, it seems at least somewhat unjust to count them."). As this Part contends, courts seem to base their decisions about permissible and impermissible forms of sex discrimination at least in part on precisely such group equality-of-opportunity considerations.

99. For examples of this group-based equality-of-opportunity conception, see Moens, supra note 95, at 44 ("International instruments such as the European Community ... Equal Treatment Directive and the Multilateral Human Rights Treaties further equal opportunity by stipulating that race and sex are irrelevant to the satisfactory performance of most jobs."); Michel Rosenfeld, Affirmative Action, Justice, and Equalities: A Philosophical and Constitutional Appraisal, 46 OHIO ST. L.J. 845, 904 (1985) ("Such characteristics as race or gender (as opposed to abilities, talents, or professional skills) are generally not inherently relevant to the allocation of scarce goods according to the ideal of equality of opportunity."); Siegel, supra note 95, at 91 (explaining that formal race talk insists that race is a trait that has no social relevance). Courts have also adopted this group-based conception of equality of opportunity, making clear that equality of opportunity requires that groups, not simply individuals, face essentially the same range of public-sphere opportunities. See Griggs v. Duke Power Co., 401 U.S. 424, 432 (1971) (stating that Title V1I prohibits "procedures or testing mechanisms that operate as "built-in headwinds' for minority groups"); Connecticut v. Teal, 457 U.S. 440, $448-49$ (1982) (same). For a discussion of the reasons this vision of equality of opportunity is problematic and at root illiberal, see YURACKO, supra note 10. 
about the nature of relevant job criteria and its substantive contention that women and men should face basically the same number, type, and range of job options, offers more promise for explaining the courts' BFOQ decisions. A concern for group-based equal opportunity helps to explain why courts distinguish in the ways they do between privacy and sexualtitillation cases and why courts are far more permissive of sex discrimination in the former than in the latter.

\section{a. Evidence of Judicial Concern for Group-Based Equality of Opportunity}

Courts worry explicitly in privacy cases about whether the exclusion of persons of one sex from a particular job will affect the general range of employment opportunities available to individuals of that sex compared with the range available to individuals of the other sex. In response to this concern, courts have created a type of balancing test in these cases. The test weighs the importance of the privacy interests at stake against the effect that sex-based hiring would have on the range of job opportunities available to the excluded sex.

In EEOC v. Hi 40 Corp., for example, defendant Physicians Weight Loss Centers argued that sex was a BFOQ for the position of weight-loss counsclor because the overwhelmingly female clientele of its weight-loss centers did not feel comfortable having their bodies measured by men or receiving counseling from them. ${ }^{100}$ In concluding that sex discrimination was impermissible in the hiring of weight-loss counselors, the district court focused explicitly on the harmful consequences discrimination in this context would have on the job opportunities of men as a group. The court noted that in considering whether sex discrimination was permissible in cases where customer privacy was at issue, the court had to balance the privacy interests of the customers against the impact of exclusion on members of the disfavored sex. ${ }^{101}$ If the effects of exclusion on the employment opportunities of the potentially excluded sex were minimal, the court explained, then the discriminatory hiring would be permitted. ${ }^{102}$ Conversely, if the effects of exclusion on the employment opportunities of the potentially excluded sex were severe, then a "minimal intrusion on the privacy of customers must be tolerated," and sex-based hiring would not be permitted. ${ }^{103}$

\footnotetext{
100. EEOC v. Hi 40 Corp., 953 F. Supp. 301 (W.D. Mo. 1996).

101. Id. at 304 .

102. Id. See also Robino v. Iranon, 145 F.3d 1109, 1110-11 (9th Cir. 1998) (upholding women's prison's policy of hiring only female guards to six posts requiring guards "to observe the inmates in the showers and toilet areas," and concluding that the court did not need to reach the question of whether the privacy issues raised in this case were sufficient to justify the sex-based hiring in these positions because of the policy's negligible impact on men's overall job opportunities in the prison).

103. Hi 40 Corp., 953 F. Supp. at 304.
} 
Similar balancing tests have been used to protect group-based equality of opportunity in other cases as well. In Hardin v. Stynchcomb, for example, the Eleventh Circuit rejected the argument of the county sheriff's department that sex was a BFOQ for positions in the male section of the county jail. ${ }^{104}$ The sheriff's policy of assigning new deputy sheriffs to the county jail for at least their first six months severely limited women's lawenforcement opportunities in the county, since the sheriff would consider hiring female deputy sheriffs only when positions were available in the female section of the jail. ${ }^{105}$ The court noted that the sheriff's assignment policy "all but eliminate[d] the opportunity of women to gain employment with the Sheriff's Department" and held that the defendants had to prove that "because of the nature of the operation of the business they could not rearrange job responsibilities in a way that would eliminate the clash between the privacy interests of the inmates and the employment opportunities of female deputy sheriffs." 106 The court concluded that defendants had failed to make this showing. ${ }^{107}$

Similarly, in Norwood v. Dale Maintenance System, Inc., the court made clear that " $[\mathrm{w}]$ hen privacy considerations of clients or guests serve as a reason for hiring only members of one sex ... the defendant must also prove that no reasonable alternatives exist to its gender-based hiring policy." 108 The court in Norwood upheld the defendant's sex-based hiring of washroom attendants only because the defendant had shown that no reasonable alternatives existed to the same-sex hiring policy. ${ }^{109}$

104. 691 F.2d 1364 (11th Cir. 1982).

105. Id. at 1367.

106. Id. at 1369,1371 .

107. The court noted that:

Defendants have failed to prove that it is essential to the functioning of the Sheriff's Department that all new Deputy Sheriffs 1 be initially assigned to the Fulton County Jail. Defendants have also failed to prove that they cannot rearrange job responsibilities so that female deputies assigned to the male section of the jail will not have to perform duties that impinge upon inmate privacy rights. Id. at 1374.

108. 590 F. Supp. 1410, 1415-16 (N.D. 111. 1984).

109. Id. at 1417-23. See also Gunther v. lowa State Men's Reformatory, 612 F.2d 1079, 1081-82, 1086-87 (8th Cir. 1980) (invalidating a policy barring women from jobs at above the Correctional Officer I level because the state failed to show that it could not reasonably rearrange job responsibilities to protect inmate privacy without denying women access to jobs); Brooks v. ACF lndus., $537 \mathrm{~F}$. Supp. 1122,1132 (S.D. W. Va. 1982) (allowing sex-based hiring of janitors where such positions necessarily involved the cleaning of men's bathhouses because "[n]o scheme suggested by plaintiff as a means of resolving the conflict between the female employee's asserted right so to be assigned [to the janitorial department], on the one hand, and the privacy rights of those male users, on the other, would be feasible or reasonable."). 


\section{b. Explaining Permissible Sex-Based Discrimination: Symmetry of Exclusion}

Although courts have made their concern about group-based equal opportunity explicit only in privacy cases, this concern also helps to explain courts' far greater willingness to permit sex discrimination in privacy cases than in sexual-titillation cases. Privacy-based BFOQ cases involve a symmetry of exclusion that is absent in sexual-titillation cases. As a result, permitting sex discrimination in sexual-titillation cases is far more dangerous to a group-based equal-opportunity ideal than is sex discrimination in privacy cases.

There is at least a theoretical parity to sex-based hiring on behalf of privacy: while women may be denied certain jobs to protect men's privacy, men will be denied the same range of jobs to protect women's privacy. ${ }^{110}$ For example, in Jones v. Hinds General Hospital, the hospital sought to engage in sex-based hiring and firing in order to have female nurses available to perform certain sensitive procedures on women and male orderlies available to perform sensitive procedures on men. ${ }^{111}$ In Norwood, the employer sought to engage in sex-based hiring for daytime washroom attendants to ensure that women's washrooms would always be cleaned by a female attendant and men's washrooms would always be cleaned by a male attendant. ${ }^{112}$ Although in both cases individuals were denied particular employment opportunities because of their sex, in neither case did the discrimination serve to exclude individuals of one sex disproportionately from a particular type of employment opportunity.

In practice, privacy interests do not always lead to perfect symmetry of exclusion. For instance, the exclusion of male nurses from working in obstetric and gynecological units at hospitals to safeguard the privacy of expectant mothers does not have a symmetrical form of female exclusion. ${ }^{113}$ Similarly, the exclusion of women from positions as prison guards in male prisons is asymmetrical because there are far fewer women in prison than men and hence women are excluded from significantly more correctional jobs. At least in some instances, however, courts recognize the asymmetry of the exclusion and give the desired discrimination heightened scrutiny.

For example, courts have recognized the asymmetry in the prison context and are for that reason extremely reluctant to permit men's prisons to

\footnotetext{
110. The exclusion is, in a sense, "separate but equal."

111. 666 F. Supp. 933 (S.D. Miss. 1987).

112. Norwood v. Dale Maint. Sys., 590 F. Supp. 1410 (N.D. Ill. 1984).

113. There is a lack of symmetry both in the narrow sense that there obviously does not exist a division of the hospital scrving men who are having babies from which female nurses are excluded, and in the broader sense that there is not a comparable area of male medicine from which female nurses are excluded.
} 
discriminate on the basis of sex..$^{114}$ Instead, courts often require prisons to restructure jobs to permit women to do them without violating inmate privacy. ${ }^{115}$ Interestingly, courts are more permissive of attempts by women's prisons to exclude male guards. ${ }^{116}$ This is probably the case both because the combined privacy and safety concerns of the female inmates seem stronger than the privacy concerns of the male inmates ${ }^{117}$ and because the threatened loss of overall job opportunities for men is less severe. ${ }^{118}$

Although courts have permitted the exclusion of male nurses from obstetrics and gynecology departments in hospitals and have not focused on the asymmetrical nature of the job loss in that situation, I suspect that this is due, at least in part, to a sense among judges that, because nursing is

114. See, e.g., Braasch v. Gunter, No. CV83-L-459, 1985 WL 3530, at*13 (D. Neb. July 15, 1985) (holding that sex was not a BFOQ for guards at a male-only penitentiary because the guard duties of even those in contact positions could be structured so as to protect inmate privacy adequately without excluding women from employment opportunities); Bagley v. Watson, 579 F. Supp. 1099, 1105 (D. Or. 1983) (holding that sex was not a BFOQ for guards in a male prison even if the female guards would see the male prisoners in states of undress and conduct pat-down frisks of the male inmates, because the privacy preferences of male inmates did "not justify discrimination against women in employment”); Griffin v. Mich. Dep't of Corr., 654 F. Supp. 690, 703 (E.D. Mich. 1982) (holding that sex is not a BFOQ for correctional officers in all-male prisons, even if the female guards would likely view male inmates naked, because male inmates did not have a protected privacy right against being viewed naked by female correctional officers); Coble v. Tex. Dep't of Corr., Civ. A. No. H-77707, 1982 WL 1578, at*11 (S.D. Tex. Dec. 20, 1982) (holding that women cannot be excluded from correctional-officer positions in male prisons but that they may be excluded from particular work responsibilities that involve viewing inmates showering, dressing, or being strip-searched).

115. See supra notes 104-07.

116. See Torres v. Wis. Dep't of Health \& Soc. Servs., 859 F.2d 1523, 1532 (7th Cir. 1988) (en banc) (holding that a prison for women seeking to exclude men from guard positions on the grounds that having only female guards would promote prisoner rehabilitation did not need to present empirical studies to support the prison's contention about the importance of female-only guards and concluding instead that the prison administrators' judgments were entitled to "substantial weight" and deference). But see Forts v. Ward, 621 F.2d 1210 (2d Cir. 1980) (holding that the privacy interests of female prisoners did not require exclusion of male guards, because the privacy interests of female inmates could be adequately protected through other measures).

117. See Robino v. Iranon, 145 F.3d 1109, 1111 (9th Cir. 1998) (noting that the hiring of women only to six "first watch" positions in a women's prison was justified not only because the employment effect on male correction officers was minimal but also because the prison adopted the "policy of assigning only female [correction officers] to posts that raise inmate privacy or safety concerns based on the serious allegations and the ensuing problems with morale among both the inmates and the [correction officers]"); see also Jordan v. Gardner, 986 F.2d 1521, 1525-26 (9th Cir. 1993) (en banc). In Jordan, the Ninth Circuit held that a prison policy requiring male guards to conduct random nonemergency suspicionless searches on clothed female prisoners was cruel and unusual punishment in violation of the Eighth Amendment because many female inmates had been sexually abused before their incarceration. Unwanted intimate touching by male prison guards was therefore likely to cause psychological trauma. Id. at 1530-31. In reaching its holding, the court noted that "[e]ighty-five percent of the inmates report[ed] a history of serious abuse to [prison] counselors, including rapes, molestations, beatings, and slavery." Id. at 1525 . The court also concluded that "[ $t]$ he record in this case supports the postulate that women experience unwanted intimate touching by men differently from men subject to comparable touching by women." Id. at 1526. Cf. Grummett v. Rushen, 779 F.2d 491, 492 n.1 (9th Cir. 1985) (holding that pat searches performed by female guards on male prisoners did not establish an Eighth Amendment claim).

118. See supra notes 102-03 and accompanying text. 
a traditionally female job, men in these cases are not being deprived of a particularly desirable job prospect anyway. These decisions may also reflect a particularly high level of solicitude for the privacy preferences of pregnant women. It seems unlikely, for example, that if the same hospitals that exclude male nurses from OB-GYN departments were also to refuse to train male residents or hire male doctors in these units in order to protect their patients' privacy that courts would so willingly accept the exclusion of men from this socially valued employment. In such a case, courts would likely, and I think properly, find that the equality-of-opportunity interests of female and male doctors outweighed patient privacy interests.

In spite of these exceptions, sex-based hiring on behalf of customer privacy interests has a general symmetry of exclusion (and opportunity) that sex-based hiring for sexual titillation does not. All of the cases in which employers have sought to discriminate on the basis of sex in order to sell sexual titillation along with some other good or service have sought to sell female sexuality to male customers and to discriminate against men in hiring. ${ }^{119}$ This is not a coincidence: there is a much greater demand for the commodification and sale of female sexuality than for the commodification and sale of male sexuality. ${ }^{120}$ Therefore, if courts were to permit employers to define jobs freely as requiring sexual titillation, the result would be, in all likelihood, a massive asymmetry of exclusion in the work world. Employers would be able to redefine a wide range of service-sector jobs as plus-sex jobs from which men would be excluded. While there would also be some plus-sex jobs aimed at sexually arousing straight women or gay

119. See Diaz v. Pan Am. World Airways, Inc., 442 F.2d 385 (5th Cir. 1971); Wilson v. Southwest Airlines Co., 517 F. Supp. 292 (N.D. Tex. 1981). Likewise, Hooters Restaurants was sued by men who were denied server positions at the restaurants because the positions were reserved for scantily clad women. Hooters defended its policy of discriminatory hiring for its food server positions on the grounds that sex was a BFOQ for these positions. The case settled, so we have no judgment on the merits of Hooters' claim. See Elizabeth M. Adamitis, Appearance Matters: A Proposal to Prohibit Appearance Discrimination in Employment, 75 WASH. L. REv. 195, 209 n.112 (2000); Schneyer, supra note 87, at 567; Timothy K. Giordano, Comment, Different Treatment for Non-Minority Plaintiffs Under Title VII: A Call for Modification of the Background Circumstances Test to Ensure That Separate Is Equal, 49 EMORY L.J. 993, 994-95 (2000).

120. There is little statistical data available regarding the numbers of women and men in the sex industry. However, the different circulations of PLAYBOY and PLAYGIRL magazines are suggestive of the greater social demand for commodified female sexuality than for commodified male sexuality. Accounting for both newsstand and subscription sales, PLAYBOY's monthly circulation is more than five times greater than Playgirl's (Playboy's circulation is 3,150,000, compared to 575,000 for PlaygIRL). Ulrich's Periodicals Directory, at http://www.ulrichsweb.com (last visited Aug. 4, 2003). The relative pay scales of female and male centerfolds also reflects this greater social demand for commodified female sexuality. PlayboY playmates are paid $\$ 25,000$ for the monthly centerfold. Playboy Playmate Frequently Asked Questions, PLAYboy MaGazine, at http:/www.playboy.com/ playmates/faq/ (last visited May 4, 2003). In comparison, male models posing for the centerfold of PLAYGIRL are paid between $\$ 1,000$ and $\$ 10,000$, depcnding on whether the model is a celebrity and whether the model arranges independent publicity for the magazine. PLAYGIRL has never paid more than $\$ 10,000$ to obtain a centerfold model. Telephone lnterview with Michelle Zipp, Editor-in-Chief, Playgirl Magazine (Nov. 25, 2002). 
men from which women would be excluded, the exclusion would be uneven.

There is, however, something odd about arguing against women's sexualization in employment by focusing on the harms such sexualization will cause to men. Such an argument seems to miss some, if not most, of what is harmful about this type of sexualization. A more subtle slippery slope argument may more accurately describe the courts' and others' concerns about the dangers likely to be caused by the sexualization of mainstream jobs and provides another justification for courts' divergent treatment of these and privacy-based cases.

\section{c. Explaining Permissible Sex-Based Discrimination: The Slippery Slope}

The slippery slope argument focuses on the parade of horribles that would occur if employers could include sexual titillation as a job requirement for mainstream jobs. Once employers are permitted to make hiring decisions based on their desire to sell female sexual gaze objects along with other goods and services, it becomes difficult to see why employers should not also be pcrmitted to make hiring decisions based on their desire to sell not only a gendered type of sexuality but also a gendered type of allure or aura or even a particular kind of business ambience inextricably linked with workers of one sex or the other. Moreover, it is likely that the jobs linked directly or indirectly to maleness, for which an employer may hire only men, will be of higher status and higher pay than the jobs linked directly to femaleness, for which an employer may hire only women. ${ }^{121}$

Job qualifications may be thought of as falling along a continuum from technical qualifications to soft or subjective qualifications. Technical qualifications are those that are capable of discrete measurement or verification. Such qualifications may include being able to type a certain number of words per minute, being able to lift boxes of a certain weight, being able to speak particular languages, or possessing a degree in a particular field.

121. For example, many of the jobs traditionally thought of as male--such as doctor, lawyer, and airline pilot-are relatively high in pay and prestige. According to the Bureau of Labor Statistics, in 2001 , average salaries for doctors (family and general practitioners), lawyers, and pilots were $\$ 110,020$, $\$ 91,920$, and $\$ 99,400$, respectively. Many jobs traditionally thought of as female-such as nurses, secretaries, and kindergarten teachers-are relatively lower in pay and prestige. According to the Bureau of Labor Statistics, that same year, nurses, secretaries, and kindergarten teachers earned an average of $\$ 48,240, \$ 25,710$, and $\$ 41,100$, respectively. See United States Dep't of Labor, 2001 National Occupational Employment and Wage Estimates, http://www.bls.gov/oes/2001/oes_nat.htm (last visited Sept. 20, 2003). Perhaps not surprisingly, then, in the almost forty years since the passage of Title Vll, women have made great strides in entering at least some of these male fields. Women make up $27.9 \%$ of doctors and $29.6 \%$ of lawyers, but only $3.7 \%$ of airline pilots. In contrast, men have not rushed to become nurses, secretaries, or kindergarten teachers. These jobs remain overwhelmingly female, with women making up $92.8 \%$ of registered nurses, $98.9 \%$ of secretaries, and $98.5 \%$ of kindergarten teachers. See U.S. Census Bureau, Statistical Abstract of the United StATES: 2001, at 380-82, Chart No. 593. 
Although social conditions (and biological ones in the case of strength requirements) may make it more difficult for people of certain races or genders to obtain technical qualifications, the qualifications are themselves race and gender neutral.

Soft qualifications do not lend themselves to discrete measurement. They are usually assessed and deemed to exist as a result of subjective evaluations and include such things as being personable, friendly, cooperative, or authoritative. Soft qualifications can be either sex-neutral or sexspecific. Although it is probably the case that virtually all soft qualifications are more readily associated with individuals of one sex than the other, I consider soft qualifications to be sex-neutral if, as a theoretical matter, individuals of both sexes may be deemed to possess them. For example, women may be more likely to be labeled cooperative, but as a theoretical, practical, and perceptual matter men may also possess this qualification.

I reserve the term "sex-specific soft qualifications" for those qualifications that require the possessor to be of a particular sex. For example, female sex appeal may be a sex-specific soft qualification for serving food at a restaurant that is trying to sell heterosexual male sexual titillation along with food. Only women will possess the required soft qualification. Similarly, only men will be qualified for jobs in which male sex appeal or male allure are required soft qualifications. Sex-specific soft qualifications might also include being able to create or enhance a particular type of workplace environment or ambience, when the environment or ambience desired is inextricably linked to one gender or another.

Currently, courts do not permit employers to make hiring decisions on the basis of sex-specific soft qualifications except in the very narrow range of cases in which the only good being sold is a particular type of sexuality. Courts also recognize the potential equal-opportunity problems caused by permitting soft qualifications, even those that are formally sex-neutral, to be used in hiring decisions. Hiring based on soft qualifications can lead to unequal job opportunities for women and men both because it is easier to hide discriminatory animus behind subjective evaluations of an applicant's soft qualifications than behind evaluations of an applicant's technical qualifications, and because certain soft qualifications may be more readily perceived in and attributed to members of one sex. ${ }^{122}$

The potential problems associated with permitting employers to hire based on soft qualifications are made clear in Robbins v. White-Wilson

122. See, e.g., Howard v. BP Oil Co., 32 F.3d 520, 526 (1 lth Cir. 1994) (noting that subjective hiring criteria should be scrutinized more closely than objective criteria because subjective criteria can more easily mask illegal discrimination); Fowler v. Blue Bell, lnc., 737 F.2d 1007, 1011 (11th Cir. 1984) ("Where the reasons that the employer offers for rejection [of an employment applicant] are based on purely subjective factors, the defendant's burden [in rebutting the plaintiff's prima facie case] is greater."); Johnson v. Uncle Ben's, Inc., 628 F.2d 419, 426 (5th Cir. 1980) (noting that "subjective selection processes involving white supervisors provide a ready mechanism for racial discrimination"). 
Medical Clinic, Inc. ${ }^{123}$ Delores Robbins, a black woman, applied for a position as a record clerk at a medical clinic in Florida. She was interviewed for the position by the record-room supervisor and turned down. ${ }^{124}$ The supervisor eventually told Robbins that she had not been hired because she lacked a pleasant personality. ${ }^{125}$ Robbins sued the clinic for race discrimination. ${ }^{126}$ At trial, the clinic argued that a pleasant personality was a necessary qualification for the record clerk position and that Robbins's unpleasant personality was a legitimate nondiscriminatory reason for its failure to hire her. ${ }^{127}$ The district court agreed and concluded that Robbins had failed to prove that the reason was a pretext for race discrimination. Accordingly, the district court ruled in favor of the clinic. ${ }^{128}$

On appeal, the Fifth Circuit viewed the clinic's explanation of its failure to hire Robbins far more skeptically. The court noted that while a job applicant's unpleasant personality might indeed be a legitimate reason for failing to hire her, the determination of whether an applicant's personality was or was not pleasant could not be based on the applicant's race. ${ }^{129}$ Based on the testimony presented at trial, the court of appeals concluded that the supervisor whose interview of Robbins was the basis for the hiring decision equated pleasant personalities with white people and less pleasant personalities with black people. ${ }^{130}$ As a result, the court of appeals held in favor of Robbins on her race discrimination claim. ${ }^{131}$

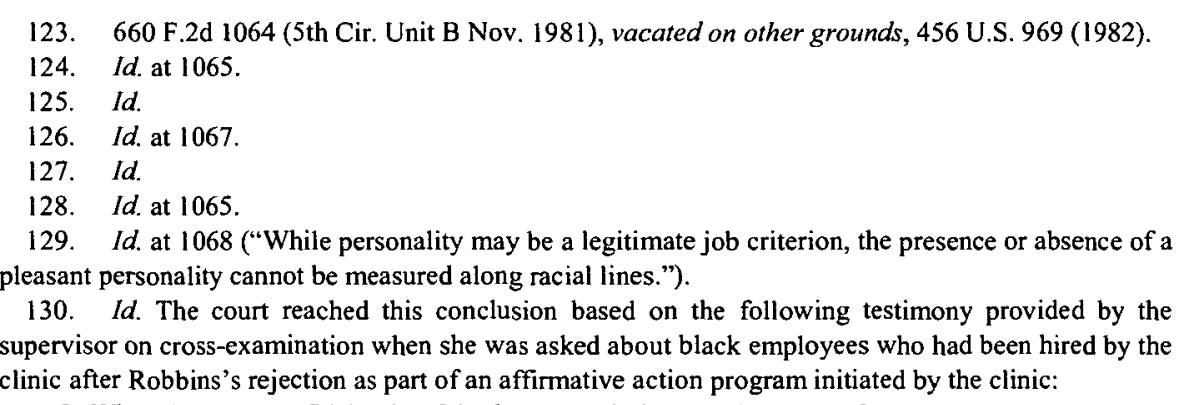

Q. What about Donna Richardson? Is she presently in your department?

A. Yes, and she's real jolly and fun to be with.

$\mathrm{Q}$. And how does she relate to the other people in the department?

A. Well, she's more white than she is black. Does that answer your question?

THE COURT: Well[,] l'm not sure I understand what you mean. Is her race black?

A. Uh-huh.

THE COURT: But she's in your thinking, more white than she is black?

A. Yeah. She's, you know, she's--her father was military, right, so if you're military, well, you know, you're not a military man but if you've been in the military you're around a lot of black and white people. You go to school with a lot of whites, right, if you're in the military, especially overseas. My kids did.

THE COURT: But you make a distinction between white people and black people in your thinking, and she's more white than black?

A. Yes, she is

THE COURT: What does that distinetion mean between black people and white people, that she's more white? 
Despite the ease with which sex-neutral soft qualifications may mask discrimination, courts consider these qualifications legitimate criteria for many, if not most, hiring decisions. ${ }^{132}$ The Eleventh Circuit, for one, has emphasized that "subjective [hiring] reasons are not the red-headed stepchildren of proffered nondiscriminatory explanations for employment decisions. Subjective reasons can be just as valid as objective reasons." $" 133$ The court explained that soft qualifications often target real skills and attributes critical to an employee's success, even though evaluation of an applicant's possession of such qualifications is necessarily subjective. ${ }^{134}$

Courts do, however, try to ensure that soft qualifications are applied and interpreted neutrally by requiring employers to state specifically the facts or observations that led the employer to conclude that a particular applicant did or did not possess the required qualifications. ${ }^{135}$ In this way, courts permit employers to make hiring decisions based on sex-neutral soft qualifications but attempt to minimize the potential equal-opportunity problems caused by such qualifications.

If, however, courts were also to permit employers to make hiring decisions on the basis of sex-specific soft qualifications, equality of opportunity problems would be impossible to mitigate. Yet, once employers are allowed to make hiring decisions based on their desire to sell a particular type of sexuality, it is difficult to explain why employers should not also be permitted to make hiring decisions based on other sex-specific soft

\footnotetext{
A. Well, she's just, I think of her as being very normal, just, I mean, being just like-1 feel like she's just a white person. I don't think of her-you're saying is she black or white. I'm saying as far as I'm concerned she's white.

132. Courts' view of the importance and legitimacy of soft qualifications in hiring should not be surprising, given the weight most judges seem to give such qualifications in their hiring of law clerks. See, e.g., Alex Kozinski, Confessions of a Bad Apple, I00 YALE L.J. 1707, 1708-09 (1991) (explaining the importance of soft qualifications such as compatibility and likability in choosing law clerks).

133. Chapman v. Al Trans., 229 F.3d 1012, 1034 (1 Ith Cir. 2000) (en banc).

134. Id. at 1033; see also Denney v. City of Albany, 247 F.3d I172, I186 (I1th Cir. 2001) (noting that "an employer's use of subjective factors in making a hiring or promotion decision does not raise a red flag"); Risher v. Aldridge, 889 F.2d 592, 597 (5th Cir. 1989) ("Subjective criteria necessarily and legitimately enter into personnel decisions involving supervisory positions.").

135. See Chapman, 229 F.3d at 1034 (holding that subjective employment criteria are legitimate as long as "the defendant articulates a clear and reasonably specific factual basis upon which it based its subjective opinion"); Byrnie v. Town of Cromwell, Bd. of Educ., 243 F.3d 93, 105 (2d Cir. 2001) (noting that subjective hiring criteria are legitimate as long as the bases for the subjective criteria are clear, specific, and honest); Robbins v. White-Wilson Med. Clinic, Inc., 660 F.2d 1064, 1067 (5th Cir. Unit B Nov. 1981) (noting that '[ $t]$ he Supreme Court's requirement that 'the defendant's explanation of its legitimate reasons ... be clear and reasonably specific' provides the plaintiff with some protection against the potential for discrimination inherent in a subjective selection process involving subjective job criteria"), vacated on other grounds, 456 U.S. 969 (1982); Millbrook v. IBP, Inc., 280 F.3d 1169 (7th Cir. 2002) (rejecting plaintiff's challenge to defendant's use of subjective criteria, such as communication skills, in hiring decisions and noting that, as a general matter, there is nothing problematic about the use of subjective evaluation criteria for job applicants).
} 
qualifications, such as a job candidate's ability to contribute to a particular type of all-male ambience.

Consider, for example, the argument made by Joe's Stone Crab in response to allegations that it discriminated against women in hiring food servers. Joe's Stone Crab is a Miami Beach landmark restaurant that has been in service since $1913 .^{136}$ In 199I, the EEOC filed a charge against Joe's, alleging that it discriminated against women in hiring food servers. From 1950 on, the serving staff at Joe's was almost exclusively male. ${ }^{137}$ Indeed, from 1986 through 1990 , Joe's 108 food servers were all male. ${ }^{138}$ In response to the EEOC's disparate treatment claim, Joe's argued that it did not intentionally discriminate against women in hiring, but instead hired so as to create a particular kind of Old World ambience associated with the highest-quality restaurants in Europe. ${ }^{139}$ This ambience, Joe's managers and experts made clear, was inextricably linked with male-only food servers. ${ }^{140}$

After a bench trial, the district court found that Joe's "sought to emulate Old World traditions by creating an ambience in which tuxedoclad men served its distinctive menu." 141 Despite this factual finding, the district court concluded that Joe's had not engaged in intentional discrimination against women. ${ }^{142}$ In reaching this conclusion, the court necessarily accepted that a job candidate's ability to contribute to the particular ambience that Joe's sought to create was a legitimate soft qualification for Joe's to make hiring decisions based upon. The court of appeals did not agree. ${ }^{143}$ According to the Eleventh Circuit, Joe's practice of hiring food servers based, in part, on the sex-specific soft qualification of their ability to contribute to the restaurant's Old World ambience was an illegitimate form of intentional sex discrimination. ${ }^{144}$

136. EEOC v. Joe's Stone Crab, Inc., 969 F. Supp. 727, 730 (S.D. Fla. 1997).

137. Id. at 731 .

138. Id. at 733. In the years after the EEOC filed its charge against Joe's, the restaurant added eighty-five food servers, nineteen of whom were women. Id.

139. Id. at $732-33$.

140. Id. at 731-32. In fact, Joe's former owner and manager Grace Weiss explicitly attributed the company's male-only hiring practices to "the ambience of the restaurant." Id. at 732 (emphasis in original). Joe's expert in restaurant management, Karen McNeil, helped elaborate precisely what kind of atmosphere Joe's was trying to create and why the appropriate atmosphere was necessarily exclusively male: “'lt has been an attitude and standard, it comes from Europe. In all of Europe you will find in all of the grade three restaurants in Europe, there is an impression that service at that high level is the environment of men, and that it ought to be that way." Id.

141. Id.

142. Id. at 741 .

143. EEOC v. Joe's Stone Crab, Inc., 220 F.3d 1263 (11 th Cir. 2000).

144. The court of appeals explained: "[T]he record extant and some of the district court's findings of fact can be read to support the alternate conclusion that Joe's management intentionally excluded women from food serving positions in order to provide its customers with an 'Old World,' fine-dining ambience." Id. at 1281 . 
As Joe's Stone Crab makes clear, there are a range of soft qualifications other than sexuality that may be exclusively, and even definitionally, associated with one sex and not the other. Once employers are permitted to make hiring decisions in order to create a particular type of sexually charged atmosphere, it becomes difficult to explain why employers should not also be permitted to make hiring decisions in order to create other kinds of environments that are associated with or require the exclusive presence of one sex. In other words, if a restaurant is permitted to hire only women because it wants to sell a sexualized atmosphere for heterosexual men, it is difficult to explain why Joe's and other restaurants should not also be permitted to make hiring decisions in order to sell an Old World male ambiencc to customers along with their food.

The slippery slope created by permitting employers to make hiring decisions based on sex-specific soft characteristics poses serious groupbased equality-of-opportunity dangers. As with hiring based on sexual titillation alone, the exclusion of women and men from jobs based on other sex-specific soft qualifications is unlikely to have the (even rough) symmetry present in privacy cases, and, unlike for hiring decisions based on sexneutral soft qualifications, there is no way to minimize the gendered nature of the exclusion. The danger is not only that women will be disproportionately excluded from certain jobs, but that they will be excluded from jobs that are the most desirable.

Given the historical roles of women and men in the workplace, positions associated with exclusively male environments are likely to be higher paying and to have higher prestige than positions associated with exclusively female environments. ${ }^{145}$ In the restaurant world, for example, permitting employers to make hiring decisions in order to create an exclusively female or male dining atmosphere would Iead, in all likelihood, to women's disproportionate exclusion from food server positions in the most high-quality, high-prestige, and high-paying restaurants. Women would face a range of lower-paying and lower-prestige food server options. ${ }^{146}$

Once sex-specific soft characteristics are deemed acceptable hiring criteria, it is unlikely that women's asymmetrical exclusion would be limited to food service. A law firm might, for example, want to sell a particularly "male" type of aggression or a distinctly "masculine" bravado along with its technical legal skills. Alternatively, a law firm might want to offer its customers the comfort of a traditional I950s corporate environment in which men in suits make executive decisions and women in dresses provide secretarial services. If employers were permitted to make hiring

145. See supra note 121 .

146. As Joe's former maître d' noted: “Traditionally, 1 mean, it's just some restaurants, when you walk in, you know there are going to be women waitresses, other restaurants you know it is going to be male waiters." Joe's Stone Crab, 969 F. Supp. 727, 732 (S.D. Fla. 1997). 
decisions in order to sell female sexuality along with other goods and services, it is difficult to see why employers should not also be permitted to sell masculinity or a particular gendered kind of atmosphere along with other goods and services. This path, though, would lead to significant disparities in the employment opportunities of women and men. ${ }^{147}$

The slippery slope version of the equality-of-opportunity argument may better address the equal-opportunity concerns courts really have. The concern with sexualizing the workplace is not simply that there will be a large number of jobs requiring female sexuality for which men cannot qualify. This is already the case in the sex industry. The true worry is that, potentially, the work world will become divided (as it once was) into distinctly male and distinctly female jobs in a way fundamentally antithetical to the goals of Title VII.

One potential weakness of the slippery slope argument may be that the slope is not as slippery as I make it out to be. ${ }^{148}$ One might argue that plausible distinctions can be drawn between the soft qualification of sexiness and other soft qualifications. That is, simply recognizing sexiness as a job requirement for plus-sex jobs does not necessarily mean that courts will be unable to prevent employers from also making a wide range of other soft qualifications job requirements. One might argue that sexiness and sexual titillation are valid and distinct soft qualifications whose recognition does not force courts to also recognize all the other fuzzy soft

147. Frederick Schauer, in his analysis of the structure and meaning of slippery slope arguments, explains that for every slippery slope argument, an equally logical slippery slope argument may be made in the opposite direction. See Frederick Schauer, Slippery Slopes, 99 HARv. L. REv. 361,381 (1985). Schauer contends that which slippery slope argument is more persuasive depends not on the logic of the arguments per se but on the empirical reality underlying them. $I d$. at 382 . The slippery slope argument opposite to the one 1 am making in this Part might bc framed as follows: If employers are not permitted to engage in sex-bascd hiring in order to sell a particular type of sexuality along with other goods and services, then it becomes impossible to justify forbidding employers from engaging in sex-based hiring when they seek to sell only or primarily sexuality. The slippery slope in this direction would lead, for example, to forbidding PLAYBoy from engaging in sex-bascd hiring of its centerfolds. There is good reason, howevcr, to believe that the slope really is more slippery in the direction with which I am concerncd than in the direction just described. In our society, jobs have historically been labeled women's jobs or men's jobs, and despite the legal move away from formally categorizing jobs in this way, many jobs are still thought of as distinctly gendered. Thus, it is a far more real danger that allowing employers to make sex-based hiring decisions in order to sell female or male sexuality along with other goods will lead to a widespread explicit gendering of jobs, than it is that forbidding sexbased hiring for plus-sex jobs will lead to a prohibition on sex-based hiring of PLAYBOY centerfolds. Moreover, the danger resulting from the slope pointing in the direction I am concemed about is more dangerous than the danger resulting from the slope pointing in the opposite direction. Because of the harm gendered job classifications would do to women's and men's actual life opportunities as well as to society's ideological commitment to a more than purely formal conception of equal opportunity, the possibility that mainstream jobs will become explicitly gendered is more dangerous than the possibility that businesses in the sex industry will not be permitted to discriminate on the basis of sex in their hiring.

I48. See Eugene Volokh, The Mechanisms of the Slippery Slope, 116 HaRv. L. Rev. 1026 (2003) (dcscribing the mechanism through which slippery slopes actually opcrate, as opposcd to the rhctorical structure of such arguments). 
qualifications that employers might name. This may be so; the slope may not in fact be so slippery. Nevertheless, group-based concerns about equality-of-opportunity harms of both the standard and slippery slope variety help to explain and justify eourts' different treatment of privacy and sexual-titillation cases.

\section{B. Customer-Focused Perfectionism}

Also explicit in the courts' distinetive treatment of privacy and sexual-titillation cases is a customer-focused perfectionism that prioritizes customer preferences based upon a belief about their importance or centrality to the holders' sense of self and self-worth. According to the courts' perfectionism, preferences for personal privacy are more integral to one's sense of self than are preferences for sexual titillation and, therefore, are entitled to more legal and social respect. This hierarchy is perfectionist, not utilitarian. ${ }^{149}$ It is based on a theory about how important particular substantive preferences are to individuals' sense of self, not on a measure of how subjectively strongly preferences are held. ${ }^{150}$ In this Section I expand upon the ways that this perfectionism, along with concerns about equality of opportunity, explains courts' divergent treatment of privacy- and sexual titillation-based BFOQ cases.

The idea that individuals' associational preferences have different degrees of legitimacy and should be given different degrees of social respect is not new. Alan Wertheimer and Larry Alexander both endorse a hierarchy of associational preferences. Wertheimer outlines several factors that affect the legitimacy of such preferences, such as their origin, bases, and mutability. ${ }^{151}$ Ultimately, though, for Wertheimer the weight that preferences should be given depends upon their social effects. ${ }^{152}$ Alexander also

149. According to their own rhetoric, courts privilege certain preferences over others because of their relative importance for human dignity, not because of their connection to personal happiness or utility. In truth, although courts use perfectionist language to describe their prioritization, the hierarchy may be motivated more by some communal sense of social acceptability than by perfectionism. It is more socially acceptable to respect an individual's preferences to have a nurse of the same sex than it is to respect an individual's preferences to have his hamburger served by a woman with bare breasts. To avoid psychoanalyzing the courts too much, however, I will accept at face value the perfectionism expressed in their opinions.

150. It does not matter that men may want to purchase sexual titillation along with their hamburgers or air travel as much as older women want to purchase personal care by same-sex nurses. Society considers the latter preference to be more important, more integral to personhood, than the former preference.

151. Wertheimer, supra note 53, at 107. Wertheimer contends: "[1]t generally seems more legitimate to count reactions to characteristics which are acquired through effort or ascribed (in some way) to the agent's free action and less legitimate to respond to innate characteristics." Id.

152. Id. at 108-12. According to Wertheimer, "[l]t may generally be unjust to count reaction qualifications based on race and sex not only because these are the sorts of innate characteristics which (in certain contexts) should not matter to the way people are treated, but because they are important social categories; that is, they are related to the distribution of social and economic benefits in a way that is both systematic and undesirable." $l d$. at 110 . 
prioritizes associational preferences largely in terms of their social impact. ${ }^{153} \mathrm{He}$ distinguishes between intrinsically immoral and intrinsically benign preferences. ${ }^{154}$ Intrinsically immoral preferences are those that "rest on erroneous judgments of others' inferior moral worth." 155 Intrinsically benign preferences, in contrast, reflect "ordinary preferences for goods and services" and are not based on beliefs about individuals' moral worth. ${ }^{156}$ Alexander emphasizes, however, that intrinsically benign preferences may still be extrinsically immoral "because of the effects on others of acting on these preferences." 157 Thus, for Alexander, as for Wertheimer, the weight that associational preferences should be given depends on their social effect rather than their status as intrinsically immoral or benign. ${ }^{158}$

Perhaps a closer parallel to the courts' approach to prioritizing preferences is Margaret Jane Radin's perfectionist theory of personhood. Radin argues that certain human attributes, relationships, and activities are integral to individuals' sense of themselves. ${ }^{159}$ To conceive of these critical attributes, relationships, and activities wholly as fungible commodities capable of being bought and sold is to do damage to our conception of personhood. ${ }^{160}$ For this reason, noncommodified versions of such attributes, relationships, and activities must be socially protected and endorsed in order to safeguard a valued and meaningful conception of personhood. ${ }^{161}$

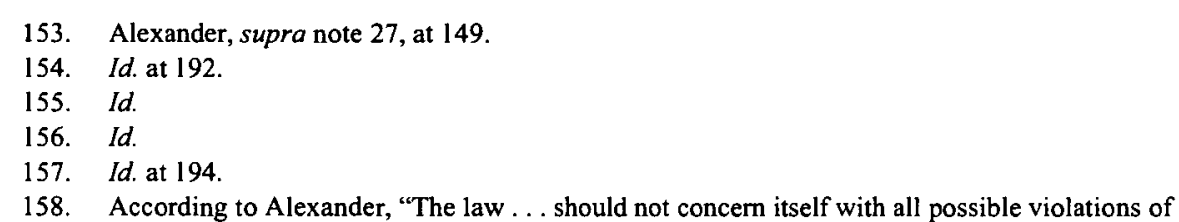
moral rights, but should instead select for prohibition those broad types of discrimination that are most likely to be immoral, intrinsically or extrinsically, that are either likely to violate victims' rights or to cause a great amount of social harm, that are least likely to be matters of discriminators' moral rights, and that are least costly to detect and establish in court." Id. at 203.

159. Radin explains that an adequate view of personhood "should understand many kinds of particulars—one's politics, work, religion, family, love, sexuality, friendships, altruism, experiences, wisdom, moral commitments, character and personal attributes-as integral to the self." Margaret Jane Radin, Market-Inalienability, 100 HARv. L. Rev. 1849, 1905-06 (1987); see also MARGARET JANE Radin, Contested Commodities 137 (1996).

160. According to Radin, "[T]0 see the rhetoric of the market-the rhetoric of fungibility, alienability, and cost-benefit analysis-as the sole rhetoric of human affairs is to foster an inferior conception of human flourishing." Radin, Market-Inalienability, supra note 159, at 1885.

161. As Radin argues, certain important attributes, relationships, and activities are more fragile than others. Certain goods, such as one's relationship with one's home and work, can comfortably and stably exist in both commodified and noncommodified forms. Other goods are more fragile, so that the existence of commodified versions of the goods threatens to destroy the more valuable noncommodified form. See Margaret Jane Radin, Reinterpreting Property 84 (1993); Radin, Contested Commodities, supra note 159, at 105-06. Sexuality, according to Radin, is a good of this more fragile sort. Radin describes the danger that commodified versions of sexuality will crowd out and make impossible noncommodified versions:

If sex were openly commodified ... its commodification would be reflected in everyone's discourse about sex, and in particular about women's sexuality. New terms would emerge for particular gradations of sexual market value. New discussions would be heard of particular 
Courts articulate a similarly perfectionist view of customer preferences in their BFOQ decisions when they distinguish between highly valued desires for personal privacy and other "mere" preferences that receive lcss weight and respect. ${ }^{162}$ Several courts have explained their decisions either permitting or prohibiting sex discrimination by relying on a quotation from the Larson and Larson treatise on employment discrimination that makes this hierarchy clear. Larson and Larson state matter-of-factly, and without explanation, that privacy preferences are superior to those for sexual titillation: "[G]iving respect to deep-seated feelings of personal privacy involving one's own genital area is quite a different matter from catering to the desire of some male airline passengers to have ... an attractive stewardess." 163 This quotation illuminates the hierarchy but does not alone make transparent the underlying perfectionism. Larson and Larson contrast deep-seated feelings with mere desires, but do not explain whether certain preferences are considered deep-seated because they reflect stronger utility measures or because they are more integral to human flourishing.

Other cases make the perfectionist underpinnings of this hierarchy clear. For example, in Local 567, American Federation of State, County, \& Municipal Employees v. Michigan Council 25, ${ }^{164}$ the district court held that the need to provide personal hygiene care for patients could justify sexbased hiring of workers at state mental health-care institutions. ${ }^{165}$ In reaching its conclusion, the court explained: "We cannot conceive of a more basic subject of privacy than the naked body. The desire to shield one's unclothed figure from view of strangers, and particularly strangers of the

abilities or qualities in terms of their market value. With this change in discourse, when it became pervasive enough, would come a change in everyone's experience, because experience is discourse dependent.

RAdin, CONTESTED COMMODITIES, supra note 159, at 133.

162. See Olsen v. Marriott Int'l, Inc., 75 F. Supp. 2d 1052, 1064 (D. Ariz. 1999) (concluding that an expert psychologist's report "merely confirms that customer preference, not privacy from the opposite sex," was the basis for the defendant's discrimination against male massage therapists and finding such discrimination not justified under the BFOQ exception); Backus v. Baptist Med. Ctr., 5 I0 F. Supp. I191, 1194 (E.D. Ark. 1981) (explaining that the protection of privacy rights will justify a job qualification based upon sex, whereas a "mere" customer preference will not); see also Fesel v. Masonic Home of Del., Inc., 447 F. Supp. I346, I352 (D. Del. 1978) (noting that the hiring of male nurses to care for female clicnts in a nursing home is not a matter "governed by the regulatory provision that customer preference alone cannot justify a job qualification based on sex. Here personal privacy interests are implicated which are protected by law and which have to be rccognizcd by the cmployer in running its business.").

163. LARSON \& LARSON, supra note 26, § 14.30 (1987); see also UAW v. Johnson Controls, Inc., 886 F.2d 871, 890 (7th Cir. 1989) (quoting LaRSON \& LARSON); Veleanu v. Beth Isr. Med. Ctr., No. 98 CIV. 7455(VM), 2000 WL 1400965, at *8 (S.D.N.Y. Scpt. 25, 2000) (same); Backus, 510 F. Supp. at $1194-95$ (same).

164. 635 F. Supp. 1010 (E.D. Mich. 1986).

165. The court made clear, though, that whether sex-based hiring was actually permissible in that case depended on the state's ability to show that there were no reasonable altcrnatives by which thc state could protect patients' privacy interests without engaging in sex-based hiring. Id. at 1014 . 
opposite sex, is impelled by elementary self-respect and personal dignity.", 166

The Ninth Circuit expressed similar sentiments in Michenfelder $v$. Sumner. ${ }^{167}$ In this case, the plaintiff, a prisoner in a maximum-security facility, sued Nevada state prison officials, alleging that their policy of conducting strip searches and otherwise exposing unclothed male inmates to view by female guards and visitors violated the Fourth and Eighth Amendments. ${ }^{168}$ Although the court found no constitutional violation in this case because female officers at the prison were not routinely present for strip searches of male prisoners and because visitors were not in fact able to view such searches, ${ }^{169}$ it noted that prisoners "retain a limited right to bodily privacy"170 and that such preferences were directly linked to individuals' self-respect and personal dignity. ${ }^{171}$

The courts' perfectionist view of customer preferences also helps to explain why privacy is treated as a negative rather than a positive right and, relatedly, why privacy preferences are respected even when they are seemingly illogical. Privacy can be thought of as a negative right to the extent that it is protected only once one expresses a desire for it. Privacy can be thought of as a positive right, however, to the extent that it is protected regardless of whether one has expressed an actual desire for it. Our society generally treats privacy as a negative rather than a positive right: an individual's choice to seek personal privacy from individuals of the opposite sex is often protected, but such personal privacy is not required. For example, while individual women can choose to see only female gynecologists and obstetricians on privacy grounds, society does not require that women shield their naked bodies from male doctors and nurses. What matters is respecting individual privacy preferences, not ensuring individual privacy per se.

Society's focus on respecting privacy preferences-rather than on ensuring personal privacy-helps to explain why courts respect privacy preferences even when they appear to be illogical. For instance, courts respect women's preferences to be cared for only by female obstetrics and

166. Id. at 1013 (quoting York v. Story, 324 F.2d 450, 455 (9th Cir. 1963)). The court went on to emphasize the connection between personal dignity and the preference for personal physical privacy: "Obviously most people would find it a greater intrusion of their dignity and privacy to have their naked bodies viewed (or any number of personal services performed) by a member of the opposite sex." Id. at 1013-14; see also Torres v. Wis. Dep't of Health \& Soc. Servs., 838 F.2d 944, 950-51 (7th Cir. 1988).

167. 860 F.2d 328 (9th Cir. 1988).

168. Id. at $329-34$.

169. Id. at 334. Contra Jordan v. Gardner, 986 F.2d 1521, 1531 (9th Cir. 1993) (en banc) (holding that a policy at a women's prison permitting random cross-gender clothed-body searches of female inmates constituted cruel and unusual punishment in violation of the Eighth Amendment).

170. Michenfelder, 860 F.2d at 333.

171. Id. 
gynecology nurses and thus permit hospitals to discriminate on the basis of sex in hiring such nurses, even when the same women are actually having their babies delivered by male doctors. ${ }^{172}$ Similarly, courts respect elderly women's preferences to be served only by female nurses, even when the same women are simultaneously being cared for by male doctors. ${ }^{173}$ Courts tolerate this seeming illogic because what is important is not protecting privacy per se, but protecting privacy preferences, which courts deem to be deeply intertwined with individuals' sense of self. ${ }^{174}$

In short, this perfectionist view of individual preferences is clearly a motivating factor in courts' decisions regarding permissible and impermissible instances of sex discrimination. This customer-focused perfectionism, combined with a concern about equality of opportunity, provides a stable and coherent account of the courts' divergent treatment of sex discrimination in sexual titillation- and privacy-based BFOQ cases. ${ }^{175}$

172. In EEOC v. Mercy Health Center, No. Civ. 80-1374-W, 1982 WL 3108 (W.D. Okla. Feb. 2, 1982), the district court held that sex was a BFOQ for nurses in the labor and delivery area of the hospital and concluded that the hospital's refusal to hire male nurses to work in the labor and delivery area was permissible. In reaching this conclusion, the court relied in part on the complaints from women about male nurses made to the hospital's two main obstetrics and gynecology doctors, both of whom were male. Id. at *3. Similarly, in Backus v. Baptist Medical Center, the district court upheld the hospital's poliey of hiring only women as nurses in the obstetrics and gynecology department. In reaching this conclusion, the court relied in part on a doctor's testimony that a majority of his patients would object to a male nurse. 510 F. Supp. 1191, 1196 (E.D. Ark. 1981).

173. See Fesel v. Masonic Homes of Del., lnc., 447 F. Supp. 1364 (D. Del. 1978) (holding that sex was a BFOQ for nurses' aides serving predominantly female patients in a retirement home because at least some of the female residents objected to being cared for by a male nurses' aide, but also noting that the female patients consented to care by male doctors).

174. There are at least two ways to understand the seemingly illogical preferences of some women for female nurses and male doctors, one explanation being more insidious than the other. First, one might attribute such preferences to a set of pollution ideas. According to Koppelman, cultural pollution occurs when things or people are considered to be out of their rightful place. See Andrew Koppelman, Are the Boy Scouts Being as Bad as Racists? Judging the Scouts' Antigay Policy 11 (Nov. 15, 2002) (unpublished article, on file with author). Koppelman argues that such idcas underlay the system of racial segregation in the post-Civil War South. Id. Similar pollution ideas may help to explain the preferences of some women (and their husbands) for female nurses, despite their acceptance of male doctors. Male nurses may just seem out of place. They may symbolize disorder and the pollution of accepted social categories. When men are nurses, they are where they do not belong; when men are doctors, they are within an appropriate social category.

The second way to understand some women's preferences for female nurses and male doctors is that the preferences reflect more of a concern about individual choice than a concern about privacy. Some women who express a preference for female nurses may choose to have male doctors precisely because they are able to choose which male doctor will treat them. A preference for female nurses may therefore be motivated not by a woman's principled objection to having her body viewed by men, but by a default presumption that in the absence of individualized choice, the woman will be happier with exclusively female rather than mixed-sex nurses. This default presumption may be based on ideas of pollution and appropriate gender rolcs, or on ideas about the average, though not absolute, superiority of women over men in caregiving responsibilities.

175. As mentioned above, although courts establish a clear hierarchy of privacy preferences over other types of preferences and indeed denigrate sexual-titillation preferences instead of treating them as on par with other preferences (e.g., a preference for Chinese food), it is impossible to know for sure whether this hierarchy is truly motivated by perfectionism, as the language of the courts' opinions 


\section{IV}

\section{The Sex Versus Plus-Sex Divide: A Better Normative Approach}

Even if courts are justified in treating sexual-titillation cases more harshly than privacy cases, it is not immediately obvious that courts should distinguish among sexual-titillation cases in the ways they do. That is, it is not clear why courts should be so much more reluctant to permit sex discrimination in businesses that seek to sell sex along with some other good or service than they are to permit such discrimination in businesses that seek to sell sex alone. This Part argues that while the courts' decisions distinguishing between sex and plus-sex businesses may be consistent with group-based equality-of-opportunity concerns and with a customer-focused perfectionism, the best normative account of these decisions is a distinct worker-focused perfectionism.

\section{A. Explaining Permissible Sex-Based Discrimination: Judicial Protection of Nonsex Jobs}

When deciding sexual-titillation cases, courts effectively do two things: (I) they rigidly divide the work world between sex and nonsex businesses, and (2) they police the boundaries between these categories to ensure that the nonsex world does not shrink, even though it may grow. Courts do not go so far as to prohibit all sex jobs, but they do rigidly sequester and control sex businesses. Businesscs may sell sexual titillation (and discriminate in hiring to do so) only if that is essentially all they are selling. ${ }^{176}$ Businesses explicitly selling sexual titillation may do so only by positioning themselves within the traditionally marginalized and stigmatized sex industry. Businesses that seek to bring sexual titillation into the mainstream by combining sexual titillation (and sex-based hiring) with the sale of other goods and services are not permitted to exist. The courts simply redefine these businesses, as they did in Southwest and Diaz, as not involving the sale of sexual titillation and not requiring sex-based discrimination. The businesses must either become sex businesses, and accept the resulting social marginalization, or become nonsex businesses and get

indicates, or by a more basic pragmatic sense that it is more socially acceptable for courts to grant individuals' desire to shield their bodies from view by individuals of the opposite sex than it is for courts to grant individuals' desire to stare at women's breasts.

176. The district court in Wilson v. Southwest Airlines Co. explained that in order for sex discrimination to be permissible, "the sex-linked aspects of the job must predominate." $517 \mathrm{~F}$. Supp. 292, 301 (N.D. Tex. 1981). The court offered examples of jobs in which "vicarious sexual recreation is the primary service provided," including those of social escort, topless dancer, and Playboy Bunny. Id. In fact, the court made clear that outside of the narrow range of job categories conventionally treated as being exclusively about sexual titillation, sexual arousal could not be any part of the job requirement. Id. at 301-02. In the court's view, jobs were either about sexual titillation or about something else. Id. 
rid of their explicit sexual-titillation dimension. ${ }^{177}$ Moreover, courts scrupulously police the divide between sex and nonsex jobs to ensure that the realm of nonsex jobs does not shrink. Although employers are generally permitted to change their business missions, impose new requirements and uniforms on employees, and fire those unwilling to comply, courts simply are unwilling to permit employers to redefine nonsex jobs as jobs requiring sexual titillation.

For example, in Guardian Capital, ${ }^{178}$ plaintiff John Plebani had worked as a waiter at the Cabaret until its owners decided to replace the male waiters with sexy female waitresses dressed in "alluring costumes."179 Recall that in this case, New York's appellate court would not permit the Cabaret to change its status as a nonsex institution and to restructure its formerly nonsex jobs in this way. ${ }^{180}$

Similarly, in EEOC v. Sage Realty Corp., ${ }^{181}$ the plaintiff, Margaret Hasselman, worked as a lobby attendant in an office building in New York City. Her employer referred to her position as that of "lobby hostess"182 and employed only women for the position. ${ }^{183}$ As part of her job, Hasselman wore a theme-based uniform that changed approximately every six months. ${ }^{184}$ In the spring of 1976 , Sage required Hasselman to wear a bicentennial uniform, which was a red, white, and blue poncho-like outfit.

177. To use again the analogy of bundled commodities, the more goods or services sexual titillation is bundled with, the more likely courts are to conclude that sexual titillation is not in fact a necessary part of the commodity at all.

178. Guardian Capital Corp. v. N.Y. State Div. of Human Rights, 360 N.Y.S.2d 937 (N.Y. App. Div. 1974).

179. Id. at 938 .

180. Id. at 939. The court based its holding only on its conclusion that the employer had not shown that sales at the Cabaret increased after the change to the all-female, food-plus-gaze object format. Since this was the Cabaret's ostensible purpose for the change, the court concluded the change was not permissible. The court did not explain why the Cabaret could not restructure its establishmcnt from a nonsex to a plus-sex establishment even if its hope of increasing sales revenues was mistaken. Id. As one of the justices noted, the Cabaret was attempting to emulate the Playboy Clubs, which a New York court had previously held were permitted to discriminate on the basis of sex in the hiring of Playboy Bunnies. Id. This different treatment of the Cabaret and the Playboy Clubs is best attributed to two related factors. First, the Playboy Clubs came into existence and became known for the sale of both food and sexual titillation several years before sex discrimination in employment became illegal. Their distinctive and established social meaning may have led courts to be more deferential to them even after the Civil Rights Act of 1964 than they would have been to a new establishment. Second, the Playboy Clubs had always sold sexual titillation along with food and were not therefore seeking to change an egalitarian nonsex business into a discriminatory plus-sex business. See St. Cross v. Playboy Club, Case No. CSF 22618-70, Appeal No. 773 (N.Y. State Div. of Human Rights Dec. 17, 1971) (stating in dicta that Playboy could discriminate on the basis of sex in hiring Playboy Bunnies). See also Playboy Enterprises, FAQs, at http://www.playboyenterprises.com/home/ (last visited July 24, 2002) (stating that the first Playboy Clubs opened in 1960, the last club closed in 1986, and during this time Playboy Clubs sold 2.5 million "membership keys").

181. 507 F. Supp. 599 (S.D.N.Y. 1981).

182. Id. at $602 \mathrm{n} .3$.

183. Id. at 609 ("Defendants adopted an all-female "lobby hostess' practice in the fall of 1975.").

184. Id. at 604 . 
Although the uniform was largely open on the sides, Hasselman was not permitted to wear a shirt under the uniform and could only wear blue dance pants on her legs. ${ }^{185}$ The uniform revealed Hasselman's thighs, portions of her buttocks, and both sides of her body. ${ }^{186}$ Hasselman sued Sage, arguing that the costume inappropriately turned her into a sex object ${ }^{187}$ and made her the target of sexual propositions, lewd comments, and obscene gestures. ${ }^{188}$ The district court ruled that the uniform requirement constituted illegal sex discrimination because the bicentennial uniform caused Hasselman to be sexually harassed. ${ }^{189}$ The court's ruling, however, is far more interesting for what it implicitly holds about the limits of an employer's right to structure its own business than for what it explicitly says. The court implicitly defined Hasselman's lobby attendant position as one that could not be sexualized.

A growing number of courts, along with the EEOC, have concluded that employers are liable for sexual harassment of their employees by nonemployees as well as by supervisors and coworkers. ${ }^{190}$ What is less clear, and has not been squarely addressed by the courts, is whether standards for nonemployee sexual harassment vary depending upon the nature of the

185. Id. at 605 .

186. Id.

187. Id. at 606. Hasselman complained about her sexualization in a letter to Sage's president. Hasselman wrote:

$[\mathrm{T}]$ he uniform is apparently designed in such a way that it is sexually revealing. . . I always see my post in the lobby as one which is charged with definite duties and responsibilities. Nonc of these duties and responsibilities... requires me to be a sex symbol in skimpy costume... . To put it simply, the uniform that 1 am required to wear is degradative [sic] to my character and offensive to me as a woman.

Id.

188. Id. at 605-06.

189. Id. at 609-10 ("In requiring Hasselman to wear the revealing Bicentennial uniform in the lobby of 711 Third Avenue, defendants made her acquiescence in sexual harassment by the public, and perhaps by building tenants, a prerequisite of her employment as a lobby attendant.").

190. See, e.g., Folkerson v. Circus Circus Enters., Inc., 107 F.3d 754, 756 (9th Cir. 1997) ("We now hold that an employer may be held liable for sexual harassment on the part of a private individual... where the employer eithcr ratifies or acquiesces in the harassment by not taking immediate and/or corrective actions when it knew or should have known of the conduct."); Hernandez v. Miranda Velez, Civ. No. 92-270I (JAF), 1994 WL 394855 (D.P.R. July 20, 1994) (finding employer liability for sexual harassment of a female manager by an official of one of employer's clients); Magnuson v. Peak Technical Servs., Inc., 808 F. Supp. 500 (E.D. Va. 1992) (finding employer liability for sexual harassment of female automobile sales trainer when she visited with customer car dealcrships); Powell v. Las Vegas Hilton Corp., 841 F. Supp. 1024 (D. Nev. 1992) (ruling that an employer could be held liable for nonemployee sexual harassment); Llewellyn v. Celanese Corp., 693 F. Supp. 369 (W.D.N.C. 1988) (finding employer liability for nonemployee sexual harassment of a female truck driver involving sexual propositions, sexual touching, and exposure by male coworkers and one male customer); Henson v. City of Dundee, 682 F.2d 897, 910 (11th Cir. 1982) (pointing out that sexual harassment can be committed by a supervisor, a coworker, or "even strangers to the workplace"); EEOC Guidelines on Discrimination Because of Sex, 29 C.F.R. § 1604.11(e) (1992) ("An employer may also be responsible for the acts of non-employees, with respect to sexual harassment of employees in the workplace, where the employer (or its agents or supervisory employees) knows or should have known of the conduct and fails to take immediate and appropriate corrective action."). 
business. It remains unclear whether the standard for determining when customer behavior constitutes sexual harassment is the same regardless of whether the leers and jeers are aimed at a librarian at the public library or a stripper at a local strip club. Some commentators have argued that the same standards should not apply. ${ }^{191}$ Indeed, sexual comments, propositions, and physical appraisals that would be completely inappropriate when aimed at the public librarian do seem less offensive and less worthy of legal redress when aimed at the performing stripper. It seems plausible to think that sexual comments that might otherwise be actionable might not be when aimed at employees who are explicitly selling sexual titillation-either alone or with other goods and services. In such contexts, the comments seem less unwelcome and less likely to alter the employees' work environment. ${ }^{192}$

To the extent that the employer in Sage Realty was attempting to define the job of lobby hostess as involving the explicit sale of sexual titillation along with various lobby services, it is not clear that the sexual comments and gestures the plaintiff received would actually constitute sexual harassment. ${ }^{193}$ The court, of course, avoided this question because it did not take seriously the possibility that the lobby hostess position could be one in which sexual titillation and lobby services were legitimately combined in one position. The court found sexual harassment by applying the standards applicable to nonsexualized jobs.

But the court did even more than this. In addition to finding Sage liable for failing to stop the harassment of Hasselman, the court ruled that Sage could not require Hasselman to wear a sexually revealing uniform. ${ }^{194}$ In contrast, it is unlikely that if a strip club was held liable for not preventing sexual harassment of its strippers by customers it would be ordered to have its strippers wear clothes. The court, policing the boundary between sexualized and nonsexualized jobs, simply would not permit Sage to change a nonsexualized lobby attendant position into an explicitly sexualized Iobby hostess position.

Similarly, in Priest v. Rotary, a hotel lounge hired the plaintiff to work as a cocktail waitress. ${ }^{195}$ When the plaintiff refused to wear clothing

191. See, e.g., Robert J. Aalberts \& Lorne H. Seidman, Sexual Harassment of Employees by NonEmployees: When Does the Employer Become Liable?, 21 PEPP. L. REv. 447, 466-67 (1994); Kelly Ann Cahill, Hooters: Should There Be an Assumption of Risk Defense to Some Hostile Work Environment Sexual Harassment Claims?, 48 V AND. L. REv. 1107, 1146-47 (1995).

192. This distinction would probably also hold for some types of touching, but not for physical assaults.

193. EEOC v. Sage Realty Corp., 507 F. Supp. 599, 605-06 (S.D.N.Y. 1981).

194. According to the court, Sage was not justified in putting Hasselman in a sexually revealing uniform because sexual titillation was not a BFOQ of the position. The court explained: "While it may well be a [BFOQ] for Sage to require female lobby attendants in its buildings to wear certain uniforms designed to present a unique image, in accordance with its philosophy of urban design, it is beyond dispute that the wearing of sexually revealing garments does not constitute a [BFOQ]." Id. at 611 .

195. 634 F. Supp. 571 (N.D. Cal. 1986). 
that was sufficiently sexually revealing, she was reassigned to the hotel coffee shop, where waitresses received significantly lower tips. While working at the coffee shop, the plaintiff was subjected to repeated sexual touching by the supervisor who had originally hired her. Again, the court held not only that the supervisor had engaged in illegal sexual harassment, but also that the supervisor had acted illegally by requiring the plaintiff to sell sexual titillation along with drinks as part of the job of cocktail waitress. ${ }^{196}$

The EEOC issued a similar ruling in a case in which the plaintiff was explicitly required to add "sexual gaze object" to her usual duties as a receptionist. ${ }^{197}$ The plaintiff was hired as a receptionist, typist, and clerk. The plaintiff's supervisor made repeated sexual requests and sexual comments to her. He then asked her to act as a hostess for visiting businessmen. As a hostess, the plaintiff was required to wear a uniform of a halter-bra top and a skirt with a thigh-high slit in the front. When plaintiff wore the costume, she was subjected to sexual comments from male visitors to the office. In ruling on the plaintiff's sex discrimination action, the EEOC concluded that the "supervisor's sexual advances constituted sexual harassment."198 The EEOC also ruled that the supervisor acted illegally when he made sexuality or sexual titillation an explicit requirement of the plaintiff's job. ${ }^{199}$ Like the courts in Sage and Priest, the EEOC simply would not allow the employer to explicitly sexualize this form of employment or employee. Thus, courts permit sexiness requirements for a small set of traditionally sex-focused jobs but are vigilant in excluding explicit sexiness requirements from other jobs in the work world. ${ }^{200}$

196. Id. at 581. The court explained: "Title VII is ... violated when an employer requires a female employee to wear sexually suggestive attire as a condition of employment. Plaintiff Priest established a prima facie violation of Title VII by demonstrating that defendant Rotary removed her from her full-time, permanent employment as a cocktail lounge waitress because she refused to wear such sexually suggestive dress. Defendant Rotary failed to articulate any legitimate non-discriminatory reason for the imposition of the dress requirement on Ms. Priest." Id. (internal citations omitted).

I97. EEOC Decision No. 8I-I7, I98 I WL 40388 (Feb. 6, 1981).

I98. Id. at*3.

I99. According to the Commission, "the requirement that [plaintiff] wear revealing attire had the purpose and effect of unreasonably interfering with [plaintiff's] work performance and created an intimidating and offensive working environment." Id.

200. This distrust of sexuality in the workplace, either as an explicit job requirement or as an implicit requirement for promotion or rewards, is also reflected in the EEOC Policy Guidance on Employer Liability under Title VII for Sexual Favoritism. See Equal Opportunity Employment Commission, Policy Guidance on Employer Liability under Title VII for Sexual Favoritism, N-9I5.048 (Dec. I2, I990), available at http://eeoc.gov/docs/sexualfavor.html. In the Guidance, the EEOC advises that the sexualization of women in a workplace (in the form of widespread sexual liaisons between supervisors and female employees), even if the sexualization is consensual, could establish a sexual harassment cause of action for other women and men in the workplace. According to the EEOC, such consensual sexualizing of women in the workplace is harmful in two primary ways. First, "[i]n these circumstances, a message is implicitly conveyed that the managers view women as 'sexual playthings,' thereby creating an atmosphere that is demeaning to women." Id. Second, "[m]anagers who engage in widespread sexual favoritism may also communicate a message that the way for women to get ahead in 
These decisions are consistent with, and may be explained by, groupbased equal-opportunity concerns of either the standard or more subtle slippery slope varieties discussed earlier. Most basically, given the far greater demand for women's sexuality, the more jobs that require sexuality as an explicit component, the more jobs will be available to women but not men. Allowing the existence of plus-sex businesses simply exacerbates the group-based equality-of-opportunity problems raised by sex-only businesses. ${ }^{201}$ More subtly, once courts permit plus-sex businesses to exist, it may be hard for them to draw the line at allowing sexuality to be a requirement for mainstream jobs. Employers may also seek to sell sexspecific soft characteristics along with their other goods and services, resulting in a heavily sex-segregated job market with women and men facing distinctly different and unequal job possibilities.

These decisions are also consistent with a variant of the customerfocused perfectionism described earlier. Courts may prevent sexuality from becoming part of mainstream businesses in order to protect the sensibilities of customers who do not want to be exposed to public sexuality and would be surprised by its presence in these arenas. When people go to strip clubs, they expect to see explicit displays of sexuality, but when people walk onto airplanes or into hotel lobbies, they do not. Prohibiting sexuality from creeping into these traditional businesses protects such customers from the jarring experience of having sexuality foisted upon them. While in privacy cases courts may have been permitting sex-based hiring in order to allow customers to shield their bodies and sexuality from exposure to others, courts in these cases may be prohibiting sex-based hiring in order to allow customers to shield themselves from unexpected displays of other people's sexuality.

\section{B. Explaining Permissible Sex-Based Discrimination: A Worker-Focused Perfectionism}

Although courts' decisions in the sexual-titillation cases are consistent with group-based equality-of-opportunity concerns and with a customerfocused perfectionism, a worker-focused perfectionism provides a stronger normative justification for the decisions. Such a rationale is hinted at but not explicitly articulated by the courts. Courts' neat division of the work world into sex and nonsex jobs, and their unwillingness to allow employers to sexualize mainstream jobs, is best justified by a worker-focused

\footnotetext{
the workplace is by engaging in sexual conduct or that sexual solicitations are a prerequisite to their fair treatment." Id.

201. Despite the equal-opportunity harms undoubtedly caused by sex businesses, courts may feel that these harms are outweighed by the autonomy interests of both employers and customers who seek to sell and buy such pure sex services. However, as the equal-opportunity harms increase, as would be the case with the allowance of plus-sex businesses, these harms may come to outweigh the autonomy interests of employers and customers.
} 
perfectionism that seeks to protect women's ability to develop as intellectual and rational actors by carving out a space for them in the work world where they cannot be formally and explicitly sexualized. This workerfocused perfectionism has two aspects: (1) an emphasis on the importance for human flourishing of one's self-development and social treatment as an intellectual rational actor, and (2) a recognition of the fragility, for women in particular, of this valued self-conception.

Contemporary perfectionist theorists uniformly endorse a vision of human flourishing that encourages the development of theoretical and practical rationality. Human flourishing, according to these theorists, requires the development of one's intellectual capacities to the degree that one can form a conception of the world and of one's aspirations in it. ${ }^{202}$ it also requires that one possess the internal and external capabilities needed to pursue those aspirations in the real world. ${ }^{203}$ Several theorists contend that sexual expression is also critical to human flourishing. ${ }^{204}$

It may be, however, that while human flourishing requires both intellectual and sexual development, it also requires a contextual disaggregation of the two. Human flourishing may require that sexual expression be confined to particular social arenas with other arenas being virtual sex-free zones. Individuals may best be able to develop the capacities and capabilities necessary for human flourishing, both of the intellectual and sexual variety, if these capabilities are developed in largely separate arenas. The need for these separate arenas seems driven primarily by the fragility of intellectual and rational development and the danger that such development will be stunted in environments where sexuality is also freely expressed and expressly valued. ${ }^{205}$

Radin has made a related argument about the fragility of sexuality. She has argued that valuable noncommodified forms of sexuality are fragile and cannot stably coexist with commodified forms of sexuality. ${ }^{206}$ The

202. See HurKa, supra note 10 , at 41 ; RAZ, supra note 10 , at $372-73$; SHER, supra note 10 , at 203-05; Nussbaum, supra note 10, at 83-85.

203. For example, Joseph Raz argues that autonomy is essential to human flourishing and that autonomy requires that an individual possess the mental abilities necessary to form intentions, develop complex plans, and connect means with their probable ends, as well as the physical capacities and social opportunities to meaningfully construct one's day-to-day life. RAZ, supra note 10 , at $372-78$. For both Thomas Hurka and George Sher, human flourishing requires the development of both theoretical and practical rationality. Individuals must have the capacity to ground their beliefs in evidence and to act upon their beliefs. See Hurka, supra note 10, at 41; SHER, supra note 10, at 203-05. Martha Nussbaum also agrees about the importance of intellectual and rational development for human flourishing. See Nussbaum, supra note 10, at 83-85.

204. For Nussbaum, human flourishing requires that an individual have the ability to control, express, and enjoy her sexuality. Nussbaum, supra note 10, at 83-85. Similarly, Margaret Jane Radin argues that sexuality-at least in its noncommodified form-is integral to a valuable conception of personhood. Radin, Market-Inalienability, supra note 159, at 1885-86.

205. See infra text accompanying notes 231-39.

206. See Radin, Contested Commodities, supra note 159 , at 133. 
commodified versions threaten to make the more valuable noncommodified versions impossible. ${ }^{207}$ Intellectual and rational agency may be similarly fragile, though endangered not by commodification but by an explicit focus on sexuality. ${ }^{208}$

The work world is an important arena for encouraging adults' intellectual growth. An explicit focus on sexuality in the work world may, however, crowd out women's intellectual development in two distinct ways. First, the explicit sexualization and sexual valuation of women may obstruct men's attention to women's intellectual and rational selves. Protecting the work world as a nonsexualized realm may be necessary in order for women to be perceived and treated by men as rational intellectual beings. Second, to the extent that women themselves focus on their sexuality and sexualized value, they too may tend to overlook and deemphasize their development as intellectual and rational individuals. Maintaining the work world as a nonsexualized realm, free of the seductive temptation of selfsexualization, may, therefore, be critical to women's intellectual and rational development.

Women in our society are always being tugged in opposite directions-they are pulled both toward being sex objects and toward being cognitive and intellectual actors. Men may occupy a similar middle position, but the position is more dangerous and unstable for women than it is for men. ${ }^{209}$ There is a real concern that women, when faced with role confusion about whether their sexual or cognitive selves are in demand, will tend to overemphasize their sexualized selves and underdevelop their cognitive selves. ${ }^{210}$ Sex discrimination law minimizes this danger by eliminating jobs that explicitly combine cognitive and sexual requirements.

Women can, of course, choose to sexualize themselves in the work world, but they must do so wholly and explicitly. They must do so under conditions in which there is no confusion that what is being sought and provided is the woman's sexual self, rather than her cognitive self. This worker-focused perfectionism ensures that those women who do not choose to become dominantly sex objects in the work world will not have their cognitive selves overwhelmed and undermined by their sexualized selves. A clearly problematic job from this perfectionist point of view is one that requires a woman to work as a chemistry professor from nine to

207. See id.

208. This argument is also reminiscent of Michael Walzer's separate spheres argument, though with human flourishing rather than the fair distribution of the social goods at stake. See generally WALZER, supra note 44.

209. See infra text accompanying notes 231-39. See also Mark Kelman, Market Discrimination and Groups, 53 STAN. L. REV. 835, 872 (2001) (arguing that it may be important, "especially for women (as individuals and as a social group), to ensure the existence of a substantial desexualized public domain")

210. See infra text accompanying notes 231-39. 
five and then perform a striptease for the administrative staff at five every afternoon. The problem with this job is not that we cannot conceive of it or make its requirements clear to all prospective candidates; the problem with the job is substantive. A job of this sort, by explicitly combining the roles of cognitive and sexual actor, leads to women's underperformance in their cognitive tasks. ${ }^{211}$ Antidiscrimination law encourages women's cognitive development by simply eliminating the sexual aspects of the job.

Although no court has ruled on a Title VII challenge to Hooters' policy of hiring only scantily clad women as food servers, a brief comparison of Hooters and the prelitigation sexualized version of Southwest Airlines will help to clarify the perfectionism I am describing and advocating. Under this worker-focused perfectionism, Hooters is less dangerous to women than was the sexualized version of Southwest. Hooters' primary product is its sexualized environment, offering a particular soft-core porn sexual fantasy involving the "All-American Cheerleader/Surfer-Girl-Next-Door."212 Cognitively, the choice to be a Hooters Girl looks a lot like the choice to be a stripper. In contrast, Southwest's dominant product was always air travel, but it used sexual titillation to boost its sales at the margin. More importantly, flight attendants at Southwest had a clear set of cognitive, nonsexual responsibilities. They were responsible for mastering and carrying out a range of safety procedures in addition to serving as eye candy. Therefore, Southwest's sexualized flight attendant positions seemingly pose a greater danger of role confusion than do the Hooters Girl positions.

Interestingly, the newly announced Hooters Air manages to avoid some of the problems of the old Southwest Airlines. Like the old Southwest, Hooters Air markets itself as an airline explicitly selling heterosexual male sexual titillation along with air travel. However, rather than sexualizing flight attendants as Southwest did, Hooters has maintained the flight attendant position as a desexualized one but has placed two explicitly sexualized Hooters Girls on each flight. ${ }^{213}$ From the perspective of the worker-focused perfectionism I advocate, the Hooters Air model is actually less problematic and less dangerous than was the Southwest model. By disaggregating the sexualized and nonsexualized jobs, Hooters Air avoids

211. See infra text accompanying notes 231-39.

212. See Hooters Careers: Hourly Employment, at http://www.hooters.com/company/careers/ hourly/ (last visited May 4, 2003); see also About Hooters, at http:/www.hooters.com/company/ about hooters/ (last visited May 4, 2003) ("The 'nearly world famous' Hooters Girls are the cornerstone of the Hooters concept.").

213. See Hooters Air Press Releases, at http://www.hootersair.com/about/press (last visited May 4, 2003) (describing the structure of the new airline); see also Julie Busman, Short-Shorts at 35,000 Feet, N.Y. Times, Mar. 23, 2004, at TR 3. 
the dangers of role confusion that are the primary focus of this perfectionism. $^{214}$

Empirical research supports both disaggregation contentions underlying the worker-focused perfectionism. First, studies suggest that the sexualization or hyperfeminization of women in the workplace alters the way they are treated by others, so that their intellectual and professional attributes are simply less likely to be recognized and encouraged. Psychologists Brad Bushman and Angelica Bonnaci conducted a study in which subjects watched sexually explicit and neutral television programs. They found that after viewing sexual images, people of both sexes had impaired memory for the substance of whatever had come next. ${ }^{215}$ What this study finds with respect to television may also hold with respect to in-person contacts. It may be that the more explicitly sexualized women are, the more distracted men are, and the less men listen to the substance of what women say. Other studies show that the simple feminization of women in the work world, even without their explicit sexualization, leads to perceptions of their diminished professional competency. ${ }^{216}$ Sandra Forsythe and her colleagues found that simply dressing female managerial job candidates in feminine clothing caused them to be perceived as less competent for managerial positions. ${ }^{217}$ One can reasonably assume that such perceptions of diminished capability also affect the way others treat and interact with these feminized women.

Additionally, the fragility of women's intellectual development may be due not only to external forces but to internal ones as well. It may be

214. Hooters Air may, however, still be problematic under the customer-focused perfectionist view to the extent that it foists sexuality upon unwitting airline passengers who desire to be free from sexuality while flying.

215. See Brad J. Bushman \& Angelica M. Bonacci, Violence and Sex Impair Memory for Television Ads, 87 J. Applied Psychol. 557 (2002). Bushman and Bonacci studied the effects that watching violent, sexually explicit or neutral television shows had on individuals' ability to recall the substance of commercials embedded within the shows. Bushman and Bonacci found that memory recall was impaired for individuals watching either violent or sexually explicit shows and suggested that the impairment might be due to the fact that individuals focus more of their attention on violent and sexually cxplicit shows than they do on neutral shows, and this increased attention decreases the amount of attention they can direct to any other competing message. Id. at 561 .

216. See infra note 217.

217. See Sandra Monk Forsythe et al., Dress as an Influence on the Perceptions of Management Characteristics in Women, 13 HoME ECON. RES. J. 112 (1984); Sandra Forsythe et al., Influence of Applicant's Dress on Interviewer's Selection Decisions, 70 J. APPLIEd PsyCHOL. 374 (1985). Forsythe and her colleagues had seventy-seven personnel administrators ( $80 \%$ of whom were male) evaluate videotapes of four applicants for a managerial position. The applicants were dressed in outfits that differed in their degree of masculinity and femininity. Participants rated video applicants as being least forccful, self-reliant, dynamic, aggressive, and decisive when they wore the most distinctly feminine dress. Interestingly, though, participants viewed the female candidates as most strongly possessing these traits not when they wore the most masculine outfit but when they wore the second most masculine outfit. The researchers hypothesized that this occurred because the participants viewed the most masculine outfit as being inappropriate for women and it therefore resulted in lower managerial competency ratings. 
that women too take themselves less seriously as intellectual and rational agents when they are focusing on their physical and sexual appearance. That is, in any given sphere, the more women focus on their bodies and appearance, the less attention they have left to focus on intellectual challenges. Intellectual development, at least for women, may therefore be best accomplished by carving out a sphere in which they cannot be explicitly and overtly sexualized. ${ }^{218}$

This has been one argument made in recent years by supporters of single-sex high schools and colleges. Although research regarding the results of single-sex education has been mixed, ${ }^{219}$ advocates of single-sex schools have often argued that girls would perform better academically in such schools because they would be freed from the pressures to selfsexualize that are prevalent in coed classrooms. ${ }^{220}$ Advocates have often

218. It is probably essential that courts carve out this sphere instead of leaving its creation to market forces. First, employers will likely have an incentive to sexualize jobs because male customers will be willing to pay a premium for sexualized services. Women may not have sufficient bargaining power to eliminate these jobs by driving up the hiring costs to such a degree that they are no longer profitable. Second, even if women had sufficient bargaining power to eliminatc these jobs, they might choosc not to. Women might believe that the pay premium attached to these jobs is sufficient to cover the value of their lost inteilectual development or they may believe that for them sexual and intellectual development are indeed compatible. It is, therefore, unlikely that the market itself would carve out this kind of sex-free zone without judicial intcrference. Courts, though, are properly guided by social concerns other than profit maximization, and courts may be in a better position than even women themselves to weigh the social costs of women's lost intellectual development.

219. See Alexander W. Astin, Four Critical Years: Effects of College on Beliefs, Attitudes and KNOwledge 232-33 (1977) (arguing that single-sex colleges are likely to lead to higher acadcmic and professional aspirations but not necessarily to higher academic achievement); Valerie E. Lee \& H.M. Marks, Sustained Effects of Single-Sex Secondary School EXPERIENCE on ATtitudes, Behaviors and Value in College (1988) (study of students in seventyfive Catholic high schools finding that single-sex schools result in advantages to giris in terms of attitudes and behavior toward academics); Cornelius H. RIORDAN, Girls AND Boys IN School: TOGETHER or Separate? 95 tbl.5.2 (1990) (finding that girls in single-sex schools outscore girls in coed schools on general aeademic ability tests, with the most notable diffcrences on science tests); Ed Cairns, The Relationship Between Adolescent Perceived Self-Competence and Attendance at Single-Sex Secondary School, 60 BRITISH J. EDuc. PsychoL. 207, 210 (1990) (concluding, based on a study of 2,890 sixteen-year-olds in their last year of compulsory education in Northern lreland, that "being a pupil at a single-sex school may contribute to an increased sense of cognitive compctence and a more inner-oriented locus of control"); Valerie E. Lee \& Anthony S. Bryk, Effects of Single-Sex Secondary Schools on Student Achievement and Attitudes, 78 J. EDUC. PsychoL. 381 (1986) (showing that single-sex schools perform better than coed schools in terms of student academic achievemcnt, faculty-student interaction, inteilectual self-esteem, and all aspects of a student's experience except for social life). But see Am. Ass'n of Univ. Women, Separated By Sex: A Critical Look at SingleSEx Education for Girls 22 (1998) (asserting that studies on single-sex classes have not shown improved achievement among girls); Herbert W. Marsh, Effects of Attending Single-Sex and Coeducational High Schools on Achievement, Attitudes, Behaviors, and Sex Differences, 8I J. EDUc. PSYCHOL. 70 (1989) (noting that some of the seeming benefits of single-sex schools may be attributed to the fact that these private schools are likely to be more competitive than public schools).

220. See Am. Ass'n of UnIv. Women, supra note 2 I9, at 34 (noting that studies show that "girls in single-sex schools may draw greater confidence from academic competence, whereas girls in mixedsex contexts draw more esteem from physical appearance"); Kristin S. Capliec, The Case for Public Single-Sex Education, 18 HARv. J.L. \& PUB. PoL'y 227, 242 (1994-95) (arguing that single-sex schools 
relied on anecdotes or intuition to support their contentions that girls are likely to be sexualized in coed schools and that such sexualization leads to diminished academic performance. 221

Recent work in psychology has shown that these dangers are real. ${ }^{222}$ Sexualization of girls and women does seem to impair their intellectual focus and performance. In a 1997 article, psychologists Barbara Fredrickson and Tomi-Ann Roberts outline what they call "objectification theory" to describe and explain the experiential effects on girls and women of their pervasive social sexualization. ${ }^{223}$ The authors rely on extensive research showing the frequency with which women's bodies are the objects of men's sexualized gazes in interpersonal encounters and the frequency with which women are depicted as sexualized bodies in the visual media. ${ }^{224}$ "[T]he sexual objectification of the female body," they conclude, "has clearly permeated our cultural milieu; it is likely to affect most girls and women to some degree, no matter who their actual social contacts may be."225

The authors further argue that the pervasive social sexualization of girls and women causes them to internalize the observer's perspective and, "at some level, [to] treat themselves as objects to be looked at and evaluated." 226 This internalization of the sexualized gaze leads, not surprisingly, to a preoccupation among girls and women with their own physical appearance. $^{227}$ One consequence of this self-objectification, the authors

have advantages for girls because the single-sex environment frees girls to focus on their academic achievement rather than on their sexual attractiveness).

221. See Liz Vivanco, New Charter School Is for Girls Only, Chi. Sun-Tımes, Aug. 22, 2000, at 6 (quoting a fourteen-year-old student at a Chicago charter school for girls explaining the distraction sexuality poses to girls in school: "WWhen you're in high school with boys, it's a distraction. Girls try to look good instead of trying to do well in school'"). Similarly, in his dissent in Mississippi University for Women v. Hogan, 458 U.S. 718 (1982), Justice Powell expressed his belief that students' focus on their sexual development necessarily detracts from their focus on their intellectual development in school. Powell opined that a single-sex school "can free its students of the burden of playing the mating game whilc attending classes, thus giving academic rather than sexual emphasis." Id. at 739 n.5 (Powell, J., dissenting).

222. See infra text accompanying notes 231-39.

223. Barbara L. Fredrickson \& Tomi-Ann Roberts, Objectification Theory: Toward Understanding Women's Lived Experiences and Mental Health Risks, 21 PsYCHOL. WOMEN Q. 173, 173-206 (1997). According to Fredrickson and Roberts, a woman is sexually objectified

whenever a woman's body, body parts, or sexual functions are separated out from her person, reduced to the status of mere instruments, or regarded as if they were capable of representing her. In other words, when objectified, women are treated as bodies - and in particular, as bodies that exist for the use and pleasure of others.

Id. at 175 (citation omitted).

224. Id. at 176-77.

225. Id. at 177 .

226. Id.

227. Id. The authors point out, however, that given the real difference that women's physical beauty makes for their life opportunities, this preoccupation with appearance is not simply narcissism but a sensible attempt to take some control over and anticipate the ways that others will treat them. Id. at 178. The authors cite numerous studies showing that physical attractiveness for women correlates 
contend, is that it impedes women's ability to reach peak motivational states. ${ }^{228}$ According to the authors, a person reaches peak motivational states when that person is "fully absorbed in challenging mental or physical activity." 229 Women's self-objectification and "habitual body monitoring" divides their attention, making them unable to focus fully on intellectual or physical tasks. ${ }^{230}$

In a 1998 article, Fredriekson, Roberts, and their colleagues sought to test empirically the impact women's self-objectification had on their ability to perform intellectually demanding tasks. ${ }^{231}$ The researchers tested this effect by having male and female students take a challenging math test while trying on either a swimsuit or a sweater. The swimsuit was meant to trigger, at least for women, the same body consciousness caused by their social sexual objectification.

The study was conducted on eighty-two undergraduate students at the University of Michigan, forty-two women and forty men. ${ }^{232}$ Participants were told they were taking part in a study concerning "emotions and consumer behavior." ${ }^{233}$ After first being asked to evaluate a fragrance to bolster the researchers' cover story, participants were left alone in a room and told over headphones to try on either a swimsuit or a sweater. Female participants were randomly assigned to try on either a one-piece swimsuit or a V-neck sweater. Male participants were randomly assigned to try on either swim trunks or a crew-neck sweater ${ }^{234}$ While wearing either the swimsuit or the sweater, participants completed questionnaires asking how they felt about themselves both generally and at that moment. Participants were then asked, again via headphones, to complete a math test, which they were told was unrelated to the study.

Fredrickson and her colleagues found that individuals in the swimsuit were more focused on their bodies and described themselves more in terms of their bodies than did individuals wearing the sweaters. ${ }^{235}$ According to the researchers, wearing the swimsuit caused an increase in selfobjectification-an increase in the feeling that "I am my body" - for both women and men as compared to the women and men wearing the

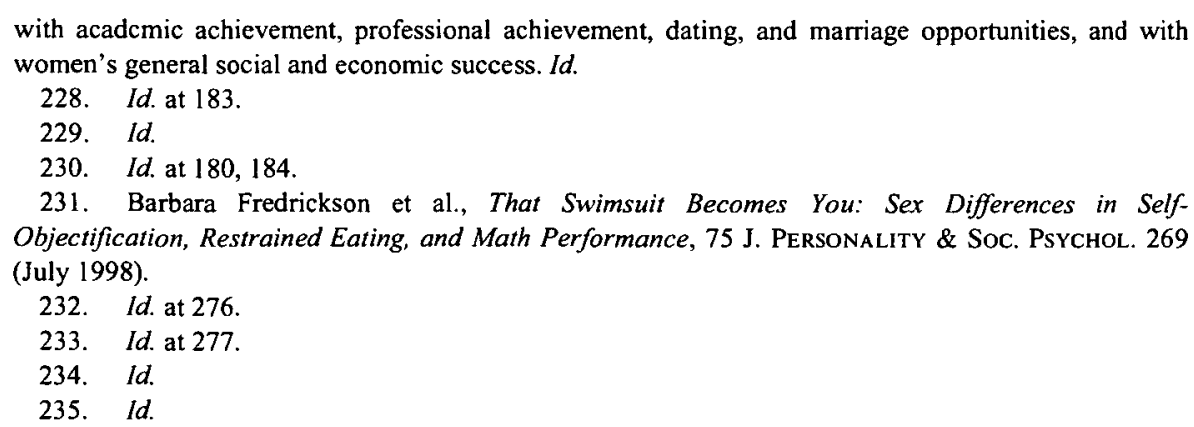


sweater. ${ }^{236}$ Yet, this self-objectification differed in both its nature and effect for the female and male students.

Wearing the swimsuit prompted women to feel an increase in shame about their bodies but did not raise such feelings of shame in men. ${ }^{237}$ More importantly, wearing a swimsuit actually impaired women's, but not men's, intellectual performance. Controlling for students' past performance on standardized math tests, the researchers found that women wearing the swimsuits performed significantly worse on the math test than did women wearing the sweaters. Men's performance on the math test was not affected by what they wcre wearing. ${ }^{238}$ The researchers concluded that women's self-objectification "does indeed draw on women's attentional resources and disrupt[s] their mental performance."239

These findings support four key contentions about the impact of social sexualization on women. First, placing women in physically revealing outfits causes them to focus additional energy and attention on their bodies. Second, when women focus additional energy on their bodies, they focus less energy on other tasks, resulting in diminished intellectual performance. Third, women's self-objectification and subsequent diminished intellectual performance may occur even if women are not in fact being sexually viewed and evaluated by men. Simply by being instructed to wear certain kinds of clothes, women can be made to focus additional energy on their bodies at the expense of other tasks even if no other individual is assessing or even viewing their bodies in the revealing clothing. Finally, selfobjectification is harmful for women in ways that it is not for men. ${ }^{240}$

236. Id. The researchers describe self-objectification as a preoccupation with physical appearance. ld. at 270-71.

237. Body shame was measured based on participants' degree of endorsement of statements such as "I wish I were invisible," "I feel like covering my body," and "I wish I could disappear," and on participants' ratings of how much they would like to change specific attributes of their bodies. Id. at 273.

238. Id. at 279 .

239. Id. at 280 . These findings have been supported by two follow-up swimsuit-sweater studies exploring the effect of self-objectification on responses to a Stroop color-naming task. Researchers found that women were slower in completing the task when wearing the swimsuits than when wearing the sweaters. Email from Diane Quinn, Dep't of Psychology, Univ. of Connecticut (Sept. 3, 2002) (on file with author) (describing results of unpublished study).

240. The findings of Fredrickson and her colleagues are consistent with the theory of stereotype threat documented by Claude Steele and others. Steele's theory posits that group members underperform on tests precisely because they are concerned that poor performance will confirm negative stercotypes about members of their group and create stereotyped perceptions of their own ability. See Claude M. Steele, A Threat in the Air: How Stereotypes Shape Intellectual Identity and Performance, 52 AM. Psychologist 613 (June 1997). Steele has shown, for example, that African Americans who take challenging intellectual tests that might reinforce negative social stereotypes about African Americans as a group underperform compared to comparable whites given the same test and comparable Afriean Americans taking the test under conditions in which the stereotype threat was removed. Steele contends that the threat of confirming the negative stereotype of one's group depresses performanee, at least in part, because the threat causes the test taker to divide her attention between the challenging task at hand and her concern about confirming, through her poor pcrformance, the negative 
The worker-focused perfectionism, emphasizing the importance for women's intellectual development of maintaining a sphere of the work world in which women cannot be explicitly sexualized, provides a stronger justification for the courts' decisions in the sexual-titillation cases than do equal-opportunity concerns of either the standard or slippery slope variety. Standard group-based equal-opportunity arguments against sexualizing mainstream jobs focus on the harms sexualization would do to the job opportunities of men. Men are already denied job opportunities that are available to women in the sex industry, and this inequality of job prospects would certainly be exacerbated if sexuality could be sold explicitly along with other goods and services. Yet, the worker-focused perfectionism focuses attention more appropriately on the harms that sexualizing women in the workplace does to women themselves. While the harms to men in terms of lost job prospects-for positions that are generally low-skill and lowprestige-are real, more significant are the harms that women's publicsphere sexualization does to women's ability to develop as full intellectual and rational actors. Slippery slope equality-of-opportunity arguments do focus on the harm that sexualizing mainstream jobs does to women, but such arguments suffer from the weakness of all slippery slope argumentsone must accept that the slope in question is indeed slippery. The advantage of the worker-focused perfectionism is that it properly focuses attention on the most significant harm at stake and does not require agreement about the slipperiness of the slope from sexualized jobs to other types of sex-specific jobs.

This worker-focused perfectionism also proves a stronger justification for the courts' sexual-titillation decisions than does a theory of customerfocused perfectionism aimed at shielding individuals from exposure to unwanted public sexuality. Even if one agrees that the ability to shield oneself in this way is important for human flourishing, it is not at all clear that a rigidly bifurcated work world is necessary to achieve this goal. The advantages of having such clearly defined sex and nonsex work worlds are clear. Customers who wish to be shielded from public sexuality know that they should avoid sex businesses and that they will be "safe" from sexuality in nonsex businesses. However, given that plus-sex businesses generally try to distinguish themselves from their more traditional nonsex counterparts, it may not be very difficult at all for customers to distinguish between them and to avoid the former, should they so desire. It is unlikely, for example, that customers of the old Southwest or of the new Hooters Air would not

stereotype of her group. See Claude M. Steele \& Joshua Aronson, Stereotype Threat and the Intellectual Test Performance of African Americans, 69 J. Personality \& Soc. Psychol. 797 (1995). Steele has argued that a similar stereotype threat depresses women's performance on challenging math tests relative to equally qualified men. See Steven J. Spencer, Claude M. Steele et al., Stereotype Threat and Women's Math Performance, 35 J. EXPERIMENT AL Soc. Psychol. 4 (1999). 
know that these businesses were selling female sexuality along with air travel. Unless the concern is that all mainstream businesses will become sexualized, a result that seems very unlikely, it is not clear that protecting customers' ability to shield themselves from public-sphere sexuality requires that sex, when it is sold at all, be sold only in its most pure, sex-only form.

One potential problem with using a theory about the harms that sexualization causes to women's intellectual achievement in order to justify courts' unwillingness to recognize plus-sex jobs is that the jobs that are most likely to become plus-sex jobs are those that are least likely to demand intellectual achievement. It may, for example, seem implausible to contend that courts are not permitting businesses to require food servers to also act as gaze objects in order to preserve and protect food servers' ability to focus exclusively on mastering the intellectual challenges of their jobs. ${ }^{24 l}$ I think, however, this criticism underestimates both the intellectualism, or at least the genuine craftsmanship, present in many nonprofessional jobs and the dangers that sexualizing the workplace poses to all women, not only those in positions closest to the borderline between sex and nonsex jobs. Low-wage and low-skill jobs often entail a distinct and legitimate craft aspect. ${ }^{242}$ Women's ability to focus on the genuine craft component of their jobs may be undermined by sexualization in much the same way as is their ability to focus on more traditionally intellectual challenges. Moreover, although the danger of allowing jobs to be explicitly sexualized is most immediate and present for women holding those jobs closest to the borderline between the sex and nonsex worlds, the dangers to women of broad sexualization are more widespread. It is possible, for example, that if employers were permitted to make sex appeal an explicit requirement for jobs such as waitress and flight attendant, employers could also make sex appeal an explicit requirement for hiring lawyers or professors. The fact that such jobs do not exist is probably more a function of the state of current antidiscrimination law than of their social inconceivability. Additionally, to the extent that an increasing number of the jobs available to women in the workplace require the explicit sale of their sexuality, this fact alone may cause women to focus heightened attention on their sexual valuation at the expense of their intellectual development.

To some, the desexualized work world I advocate may seem both sad and unnecessary. Vicki Schultz, for example, argues that sexual banter and conduct in the workplace can be empowering, pleasurable, and deeply

241. Of course, these food servers' sexualization may prevent them from seeing or taking avenues for exit to more intellectually challenging jobs.

242. See generally Barbara Ehrenreich, Nickel and Dimed: ON (Not) GetTing By IN AMERICA (2001) (describing the pride many low-wage workers take in performing the craft aspects of their work well). 
humanizing for women and men. ${ }^{243}$ Schultz argues that many employers have gone too far in "sanitizing" their workplaces of all sexualized interactions while ignoring more significant issues like the exclusion or segregation of women in the workplace. As Schultz's work highlights, it is important to keep in mind that many different types of sexuality may emerge in the workplace. 1 have been focusing here on employer-mandated workplace sexuality in cases in which employers make acting as a sex object a requirement for otherwise nonsexual jobs. This object-oriented and employer-imposed sexuality is quite distinct from the kind of agencyoriented and employee-imposed sexuality that Schultz argues may be a positive presence in the work world. I am perhaps less sanguine than Schultz about the benefit of even this kind of sexuality in the workplace, but it is significantly different from the kind of job sexualization with which I have been concerned in this Article.

\section{CONCLUSION}

This Article has sought to explain and justify the line drawing courts engage in between permissible and impermissible forms of sex discrimination in the workplace. Although I began by taking the courts at their word when they said that they were basing such decisions on the nature or "essence" of the businesses involved, I have shown that such an analysis, under any plausible conception of business essence, simply cannot explain the courts' decisions. I have sought, therefore, to provide a more stable and coherent explanation and defense for the courts' BFOQ decisions. I have shown that the courts' rulings are based not on a meaningful conception of what certain businesses require, but instead on broader conceptions of the nature and type of work opportunities that women and men should face and of the nature and degree of control that customers should have over the services they receive.

I have argued that courts are more lenient toward sex discrimination in cases involving privacy concerns than in cases involving sexualtitillation desires not because of the nature of either type of business, but because courts are rightly more concerned about the effects of permitting sex discrimination in the latter than the former. Privacy-based BFOQ cases simply have a symmetry of exclusion that sexual-titillation cases do not. Allowing discrimination in sexual-titillation cases is far more dangerous and damaging to a society that seeks to provide a similar range and type of job opportunities for women and men than is sex discrimination in privacy cases.

Moreover, I have argued that the seemingly strange distinction courts draw among sexual-titillation cases-permitting sex discrimination if a

243. See Vicki Schultz, The Sanitized Workplace, 112 YALE L.J. 2061 (2003). 
business is selling sex only but not if it is selling something else plus sexis best justified on distinctly perfectionist grounds. Encouraging women's intellectual and rational development may actually require protecting a public sphere in which they cannot be explicitly sexualized-in which they must be formally treated and evaluated as intellectual actors rather than sexual beings. The courts' rigid bifurcation of the work world and avid policing of this boundary guarantees women such a formally sex-free zone. Without doing so explicitly, courts are practicing through their BFOQ decisions a perfectionism toward women that is both benevolent and wise. By patrolling the work world and keeping sex in its corner, the courts seek to ensure that women will be able to see and treat themselves-and be seen and treated by others-as intellectual agents rather than plus-sex objects. 
